\title{
Vibrational study and thermal behavior of dihydrogenotriphosphate trihydrate of 4-aminobenzoic acid and its anhydrous new form fertilizer type NP
}

\author{
Mustapha Belhabra ${ }^{1, *}$, Ismail Fahim ${ }^{1}$, Azzedine Atibi ${ }^{1,2}$, Khadija El Kababi ${ }^{1,2}$, Ali Ouasri ${ }^{3}$, Soufiane \\ Zerraf $^{1}$, Malika Tridane ${ }^{1,2}$, Mohammed Radid ${ }^{1}$, and Said Belaaouad ${ }^{1}$ \\ ${ }^{1}$ Laboratoire de Chimie Physique des Matériaux LCPM, Faculté des Sciences Ben M'sik, B. P. 7955. \\ Bd Cdt Driss El Harti. Université Hassan II de Casablanca, Maroc \\ ${ }^{2}$ Centre Régional des métiers d'éducation et de formation Casablanca Anfa, Bd Bir Anzarane \\ Casablanca, Maroc \\ ${ }^{3}$ Centre Régional des métiers d'éducation et de formation Rabat. Maroc
}

\begin{abstract}
Chemical synthesis methods and IR spectrometry studies are reported for an organic triphosphate $\left(\mathrm{NH}_{3} \mathrm{C}_{6} \mathrm{H}_{4} \mathrm{COOH}\right)_{3} \mathrm{H}_{2} \mathrm{P}_{3} \mathrm{O}_{10} .3 \mathrm{H}_{2} \mathrm{O}$ and its anhydrous new form $\left.\mathrm{NH}_{3} \mathrm{C}_{6} \mathrm{H}_{4} \mathrm{COOH}\right)_{3} \mathrm{H}_{2} \mathrm{P}_{3} \mathrm{O}_{10}$. The hydrate compound $\left(\mathrm{NH}_{3} \mathrm{C}_{6} \mathrm{H}_{4} \mathrm{COOH}\right)_{3} \mathrm{H}_{2} \mathrm{P}_{3} \mathrm{O}_{10} .3 \mathrm{H}_{2} \mathrm{O}$ was synthetized by the ion-exchange resin method. The dehydration of $\left(\mathrm{NH}_{3} \mathrm{C}_{6} \mathrm{H}_{4} \mathrm{COOH}\right)_{3} \mathrm{H}_{2} \mathrm{P}_{3} \mathrm{O}_{10} .3 \mathrm{H}_{2} \mathrm{O}$ leads at $130^{\circ} \mathrm{C}$ to $\left(\mathrm{NH}_{3} \mathrm{C}_{6} \mathrm{H}_{4} \mathrm{COOH}\right)_{3} \mathrm{H}_{2} \mathrm{P}_{3} \mathrm{O}_{10}$ crystallizing in the triclinic system with space group P $1(\mathrm{Z}=2)\left[\mathrm{a}=14.566(6) \AA, \mathrm{b}=6.866(1) \AA, \mathrm{c}=6.445\right.$ (6) $\AA, \alpha=112.36(3)^{\circ}, \beta=94.51(1)^{\circ}$, $\gamma=95.94(7){ }^{\circ}$, and $\left.V=587.98(1) \AA^{3}\right]$. Merit's figures are $M(10)=91.9$ and $F(10)=55.6(0.0032,56)$. Its thermal behavior and kinetic study were studied by using thermal analyses TGA and DTA techniques between 25 and $600^{\circ} \mathrm{C}$.
\end{abstract}

Keywords: $p$-carboxyphenylammonium triphosphate; IR spectrometry; vibrational study; thermogravimetric and differential analyses (TGA-DTA); Kinetic; Ozawa; KAS.

\section{Introduction}

The P-carboxyphenylamine (4-aminobenzoic acid) considered as a biological molecule, has an anticoagulant and antioxidant properties. It exists naturally in foods; it is produced by essential symbiotic bacteria to metabolize constantly in the human body ${ }^{1}$. The active sites of several biological systems have kind of hydrogen bonding in hybrid compound ${ }^{2}$. Indeed, the crystal structures of 4-carboxyphenylammonium dihydrogen phosphate and 4-carboxyanilinium hydrogen sulphate compounds have been recently studied ${ }^{3,4}$. Furtherer, the $p$-carboxyphenylammonium dihydrogen-monophosphate monohydrate compound was found to consist of $\mathrm{H}_{2} \mathrm{PO}_{4}^{-}$anions, water molecules and $p$-HOOC- $\mathrm{C}_{6} \mathrm{H}_{4}-\mathrm{NH}_{3}{ }^{+}$cations ${ }^{5}$. In this structure, anions and cations are linked to each other through strong hydrogen bonds, formed by all $\mathrm{H}$ atoms covalently bonded to anions, nitrogen, carboxylic groups and water molecules. A three-dimensional complex network of hydrogen bonds ensures the cohesion of the ionic structure.
The literature contains numerous studies of solid materials containing the $\mathrm{P}_{3} \mathrm{O}_{10}$ group like $\mathrm{NH}_{4} \mathrm{ErHP}_{3} \mathrm{O}_{10}, \quad \mathrm{CuNa}_{3} \mathrm{P}_{3} \mathrm{O}_{10} .12 \mathrm{H}_{2} \mathrm{O}, \quad \mathrm{CuNa}_{3} \mathrm{P}_{3} \mathrm{O}_{10}$, $\mathrm{MgNa}_{3} \mathrm{P}_{3} \mathrm{O}_{10} .12 \mathrm{H}_{2} \mathrm{O}, \quad \mathrm{MgNa}_{3} \mathrm{P}_{3} \mathrm{O}_{10}$, $\mathrm{NiNa}_{3} \mathrm{P}_{3} \mathrm{O}_{10} .12 \mathrm{H}_{2} \mathrm{O}$ et $\mathrm{NiNa}_{3} \mathrm{P}_{3} \mathrm{O}_{10}{ }^{6-10}$. During a systematic investigation of triphosphates associated with organic matrixes, the triphosphate trihydrate of para carboxyphenylammonium $\left(\mathrm{NH}_{3} \mathrm{C}_{6} \mathrm{H}_{4} \mathrm{COOH}\right)_{3} \mathrm{H}_{2} \mathrm{P}_{3} \mathrm{O}_{10} .3 \mathrm{H}_{2} \mathrm{O}$ was prepared by the method of ion-exchange resin 11 in our laboratory ${ }^{12,13}$.

The present study reports on the chemical preparation, IR vibrational spectroscopy, thermal dehydration and decomposition by thermal analyses (TGA and DTA) of $\left(\mathrm{NH}_{3} \mathrm{C}_{6} \mathrm{H}_{4} \mathrm{COOH}\right)_{3} \mathrm{H}_{2} \mathrm{P}_{3} \mathrm{O}_{10} .3 \mathrm{H}_{2} \mathrm{O}$. The total thermal dehydration of this compound leads to the corresponding anhydrous form, which is a new triphosphate of para carboxyphenylammonium $\left(\mathrm{NH}_{3} \mathrm{C}_{6} \mathrm{H}_{4} \mathrm{COOH}\right)_{3} \mathrm{H}_{2} \mathrm{P}_{3} \mathrm{O}_{10}$. The kinetic parameters of dehydration have been studied for the title compound. Indeed, $\left(\mathrm{NH}_{3} \mathrm{C}_{6} \mathrm{H}_{4} \mathrm{COOH}\right)_{3} \mathrm{H}_{2} \mathrm{P}_{3} \mathrm{O}_{10} .3 \mathrm{H}_{2} \mathrm{O}$ 
and $\left(\mathrm{NH}_{3} \mathrm{C}_{6} \mathrm{H}_{4} \mathrm{COOH}\right)_{3} \mathrm{H}_{2} \mathrm{P}_{3} \mathrm{O}_{10}$ are binary organic fertilizers type NP (nitrogen and phosphorus) second generation and corrosion inhibitors ${ }^{14-15}$. The two triphosphates associated with para carboxyphenylammonium reported in the present work are stable in the normal conditions of temperature and hygrometry.

\section{Experimental}

$$
\mathrm{H}_{5} \mathrm{P}_{3} \mathrm{O}_{10}+3 \mathrm{NH}_{2} \mathrm{C}_{6} \mathrm{H}_{4} \mathrm{COOH}+3 \mathrm{H}_{2} \mathrm{O}
$$

The so-obtained solution was then slowly evaporated at room temperature until large prisms of $\left(\mathrm{NH}_{3} \mathrm{C}_{6} \mathrm{H}_{4} \mathrm{COOH}\right)_{3} \mathrm{H}_{2} \mathrm{P}_{3} \mathrm{O}_{10} .3 \mathrm{H}_{2} \mathrm{O}$ were obtained. The triphosphoric acid, $\mathrm{H}_{5} \mathrm{P}_{3} \mathrm{O}_{10}$, used in this reaction was prepared from an aqueous solution of $\mathrm{Na}_{5} \mathrm{P}_{3} \mathrm{O}_{10}$ passed through an ion-exchange resin 'Amberlite IR120, ${ }^{11}$. $\left(\mathrm{NH}_{3} \mathrm{C}_{6} \mathrm{H}_{4} \mathrm{COOH}\right)_{3} \mathrm{H}_{2} \mathrm{P}_{3} \mathrm{O}_{10} .3 \mathrm{H}_{2} \mathrm{O}$ is stable in the normal conditions of temperature and hygrometry. $\left(\mathrm{NH}_{3} \mathrm{C}_{6} \mathrm{H}_{4} \mathrm{COOH}\right)_{3} \mathrm{H}_{2} \mathrm{P}_{3} \mathrm{O}_{10} \cdot 3 \mathrm{H}_{2} \mathrm{O}$ was

\section{Synthesis $\left(\mathrm{NH}_{3} \mathrm{C}_{6} \mathrm{H}_{4} \mathrm{COOH}\right)_{3} \mathrm{H}_{2} \mathrm{P}_{3} \mathrm{O}_{10.3 H_{2} \mathrm{O}}$}

Single

crystals

of $\left(\mathrm{NH}_{3} \mathrm{C}_{6} \mathrm{H}_{4} \mathrm{COOH}\right)_{3} \mathrm{H}_{2} \mathrm{P}_{3} \mathrm{O}_{10} .3 \mathrm{H}_{2} \mathrm{O}$ were prepared by slowly adding dilute cyclotriphosphoric acid, $\mathrm{H}_{5} \mathrm{P}_{3} \mathrm{O}_{10}$, to an aqueous solution of para carboxyphenylammonium, $\mathrm{NH}_{2} \mathrm{C}_{6} \mathrm{H}_{4} \mathrm{COOH}$ according to the following chemical reaction:

\section{$\left(\mathrm{NH}_{3} \mathrm{C}_{6} \mathrm{H}_{4} \mathrm{COOH}\right)_{3} \mathrm{H}_{2} \mathrm{P}_{3} \mathrm{O}_{10} .3 \mathrm{H}_{2} \mathrm{O}$}

$\left(\mathrm{NH}_{3} \mathrm{C}_{6} \mathrm{H}_{4} \mathrm{COOH}\right)_{3} \mathrm{H}_{2} \mathrm{P}_{3} \mathrm{O}_{10}$ is stable in the normal conditions of temperature and hygrometry.

With the additional increase in temperature, $\left(\mathrm{NH}_{3} \mathrm{C}_{6} \mathrm{H}_{4} \mathrm{COOH}\right)_{3} \mathrm{H}_{2} \mathrm{P}_{3} \mathrm{O}_{10}$ is decomposed by evolving $\mathrm{NH}_{3}$ followed by $\mathrm{CO}_{2}$.

\section{Data Collection and Reduction}

Thermal behavior. Coupled TGA-DTA thermal analyses were performed using the multimodule 92 Setaram Analyzer operating from room temperature up to $1400^{\circ} \mathrm{C}$, in a platinum crucible, at various heating rates from 1 to $15^{\circ} \mathrm{C} / \mathrm{min}$.

Infrared spectrometry. The infrared spectra of the powdered samples of $\left(\mathrm{NH}_{3} \mathrm{C}_{6} \mathrm{H}_{4} \mathrm{COOH}\right)_{3} \mathrm{H}_{2} \mathrm{P}_{3} \mathrm{O}_{10} .3 \mathrm{H}_{2} \mathrm{O}$ and $\left(\mathrm{NH}_{3} \mathrm{C}_{6} \mathrm{H}_{4} \mathrm{COOH}\right)_{3} \mathrm{H}_{2} \mathrm{P}_{3} \mathrm{O}_{10}$ were recorded in the range 4000-400 $\mathrm{cm}^{-1}$ with a Perkin-Elmer IR 983G spectrophotometer, using samples dispersed in spectroscopically pure $\mathrm{KBr}$ pellets.

\section{Results and Discussion}

\section{Crystallographic Characterization}

- $\left(\mathrm{NH}_{3} \mathrm{C}_{6} \mathrm{H}_{4} \mathrm{COOH}\right)_{3} \mathrm{H}_{2} \mathrm{P}_{3} \mathrm{O}_{10} .3 \mathrm{H}_{2} \mathrm{O}$

$\left(\mathrm{NH}_{3} \mathrm{C}_{6} \mathrm{H}_{4} \mathrm{COOH}\right)_{3} \mathrm{H}_{2} \mathrm{P}_{3} \mathrm{O}_{10} .3 \mathrm{H}_{2} \mathrm{O}$

studied elswhere ${ }^{12,13}$ crystallizes in the triclinic system with space group $\mathbf{P}^{\overline{1}}(\mathrm{Z}=2)[\mathrm{a}=9.844(1) \AA$, $\mathrm{b}=13.086(4) \AA, \mathrm{c}=13.320(2) \AA ; \alpha=107.12(2)^{\circ}$, $\beta=106.08(1)^{\circ}, \alpha=97.87(2)^{\circ}$, and $\left.V=1530(1) \AA^{3}\right]$. also obtained using the same method, by the hydrolysis of $\mathrm{P}_{3} \mathrm{O}_{9}{ }^{3-}$ ion in aqueous solution $\left(\mathrm{NH}_{3} \mathrm{C}_{6} \mathrm{H}_{4} \mathrm{COOH}\right)_{3} \mathrm{H}_{2} \mathrm{P}_{3} \mathrm{O}_{10}$.

The product resulting from the total thermal dehydration of $\left(\mathrm{NH}_{3} \mathrm{C}_{6} \mathrm{H}_{4} \mathrm{COOH}\right)_{3} \mathrm{H}_{2} \mathrm{P}_{3} \mathrm{O}_{10} .3 \mathrm{H}_{2} \mathrm{O}$, at $130^{\circ} \mathrm{C}$, is a new anhydrous triphosphate of para carboxyphenylammonium

$\left(\mathrm{NH}_{3} \mathrm{C}_{6} \mathrm{H}_{4} \mathrm{COOH}\right)_{3} \mathrm{H}_{2} \mathrm{P}_{3} \mathrm{O}_{10}$. The reaction is the following:

\section{$\left(\mathrm{NH}_{3} \mathrm{C}_{6} \mathrm{H}_{4} \mathrm{COOH}\right)_{3} \mathrm{H}_{2} \mathrm{P}_{3} \mathrm{O}_{10}+3 \mathrm{H}_{2} \mathrm{O}$}

\section{- $\left(\mathrm{NH}_{3} \mathrm{C}_{6} \mathrm{H}_{4} \mathrm{COOH}\right)_{3} \mathrm{H}_{2} \mathrm{P}_{3} \mathrm{O}_{10}$}

$\left(\mathrm{NH}_{3} \mathrm{C}_{6} \mathrm{H}_{4} \mathrm{COOH}\right)_{3} \mathrm{H}_{2} \mathrm{P}_{3} \mathrm{O}_{10}$ crystallizes in the triclinic system with space group $\mathbf{P}_{\overline{1}}(Z=2)$. Its unit-cell dimensions are: $\mathrm{a}=14.566(6) \AA, \mathrm{b}=6.866$ (1) $\AA$, $\mathrm{c}=6.445(6) \AA, \alpha=112.36(3)^{\circ}, \beta=94.51(1)^{\circ}$, $\gamma=95.94(7)^{\circ}$, and $\mathrm{V}=587.98(1) \AA^{3}$. Merit's figures are $\mathrm{M}(10)=91.9$, and $\mathrm{F}(10)=55.6(0.0032,56)^{12}$.

\section{Vibrational study}

\section{Vibrations analysis of $\mathrm{H}_{2} \mathrm{P}_{3} \mathrm{O}_{10}{ }^{3-}$}

The anion dihydrogenotriphosphate $\left(\mathrm{H}_{2} \mathrm{P}_{3} \mathrm{O}_{10}\right)^{3-}$ supposed to be of symmetry group $\mathrm{C}_{1}$, has 39 internal vibration modes $\left[\Gamma_{\text {int }}=39 A^{\prime}(\right.$ IR, Ra) $]$. According to this hypothesis, the anionic modes of $\left(\mathrm{H}_{2} \mathrm{P}_{3} \mathrm{O}_{10}\right)^{3-}$ free are all active in Raman and Infrared thus should appear in the form of simple bands.

$$
\text { In the structure }
$$

of

$\left(\mathrm{NH}_{3} \mathrm{C}_{6} \mathrm{H}_{4} \mathrm{COOH}\right)_{3} \mathrm{H}_{2} \mathrm{P}_{3} \mathrm{O}_{10} .3 \mathrm{H}_{2} \mathrm{O}$,), space group $\mathbf{P} \overline{\mathbf{1}}$ (Group of factors $\mathrm{Ci})^{16},\left(\mathrm{H}_{2} \mathrm{P}_{3} \mathrm{O}_{10}\right)^{3-}$ The anions have a $\mathrm{C}_{1}$ site symmetry. This implies that all anionic internal modes (Table 1) generally remain infrared and Raman assets in the crystal site group. Theoretically, the presence of two units per unit of formula $(Z=2)$ doubles the number of cationic and anionic modes with Ag and Au symmetry in the group of factors $C_{i}$. In the crystal being centrosymmetric $\left(\mathrm{C}_{\mathrm{i}}\right.$ group factor), only $\mathrm{Au}$ insensitive augs are active in infrared. All modes of vibration are theoretically active in infrared and Raman. These anionic modes correspond mainly to the vibrations of the $\mathrm{PO}_{4}{ }^{3-}$ and $\mathrm{P}-\mathrm{O}-\mathrm{P}$. 
Table 1. Correlation table $\left(\mathrm{C}_{1^{---}>\mathrm{C}_{\mathrm{i}}}\right)$ for the internal vibrational modes of $\left(\mathrm{H}_{2} \mathrm{P}_{3} \mathrm{O}_{10}\right)^{3-}$.

\begin{tabular}{|c|c|c|}
\hline Point group : $\mathrm{C}_{1}$ & Site group : $\mathrm{C}_{1}$ & Factor group : $C_{i}$ \\
\hline 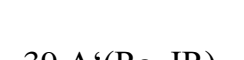 & 80 & - $39 \mathrm{~A}_{\mathrm{g}}(\mathrm{Ra})$ \\
\hline & & $39 \mathrm{~A}_{\mathrm{u}}(\mathrm{IR})$ \\
\hline
\end{tabular}

\section{Vibrations analysis of 4-carboxyphenyl ammonium}

The free 4-carboxyphenyl ammonium cation is assumed to be of $\mathrm{C}_{\mathrm{s}}$ symmetry point group, and then has 48 internal vibrational modes described as $\Gamma_{\text {int }}=$ $32 \mathrm{~A}^{\prime}(\mathrm{IR}, \mathrm{Ra})+16 \mathrm{~A}^{\prime}$ (IR, Ra). According to this assumption, the cationic modes are all Raman and Infrared active and should appear as single bands. In the structure of $\left(\mathrm{NH}_{3} \mathrm{C}_{6} \mathrm{H}_{4} \mathrm{COOH}\right)_{3} \mathrm{H}_{2} \mathrm{P}_{3} \mathrm{O}_{10} .3 \mathrm{H}_{2} \mathrm{O}$ compound, of $\mathrm{P} 1$ space group $\left(\mathrm{C}_{\mathrm{i}}\right.$ factor group) ${ }^{16}$, 4-carboxyphenyl ammonium cations have $\mathrm{C}_{1}$ site symmetry. This implies that all cationic internal modes (Table 2) usually remain infrared and Raman actives in the site group of the crystal. The presence of two motifs per formula unit $(Z=2)$ doubles theoretically the number of cationic modes having $\mathrm{A}_{\mathrm{g}}$ and $A_{u}$ symmetry in the factor group $C_{i}$. It is concluded that all vibrational modes are theoretically Infrared and Raman active. Due to the centro symmetry of the crystal, only the ungerade modes $A_{u}$ are Infrared active for the cations.

Table 2. Correlation table $\left(\mathrm{C}_{1^{---}>\mathrm{C}_{\mathrm{i}}}\right)$ for the internal vibrational modes of $\left(\mathrm{NH}_{3} \mathrm{C}_{6} \mathrm{H}_{4} \mathrm{COOH}\right)^{+}$.

\begin{tabular}{|c|c|c|}
\hline Point group : $\mathrm{C}_{1}$ & Site group : $\mathrm{C}_{1}$ & Factor group : $\mathrm{C}_{\mathrm{i}}$ \\
\hline $32 \mathrm{~A}^{\prime}(\mathrm{Ra}, \mathrm{IR})$ & & $32 \mathrm{~A}_{\mathrm{g}}(\mathrm{Ra})$ \\
$16 \mathrm{~A}^{\prime \prime}(\mathrm{Ra}, \mathrm{Ra}, \mathrm{IR})$ & $16 \mathrm{~A}^{\prime}(\mathrm{Ra}, \mathrm{IR})$ \\
\hline
\end{tabular}

The mainly crucial cationic vibration bands correspond principally to the vibrations of amino $\mathrm{NH}_{3}{ }^{+}$, carboxyl groups and benzene ring. It is to note that the distribution of the internal vibrations modes for benzene group by developing the normal coordinate analysis has been carried out ${ }^{17}$. In its free state, the $\mathrm{NH}_{3}{ }^{+}$cation has $\mathrm{C}_{3 \mathrm{v}}$ symmetry with a pyramidal geometry; the corresponding normal vibrational modes are described as non-degenerative modes $\left[v_{1}\left(A_{1}\right), v_{1}\left(A_{1}\right)\right]$, and doubly degenerated $\left[v_{3}(E)\right.$ and $\left.v_{4}(\mathrm{E})\right]$, which all active as well as in Raman and Infrared. In the 4-carboxyphenyl ammonium cation of $\mathrm{C}_{\mathrm{s}}$ symmetry, all $\mathrm{NH}_{3}{ }^{+}$modes become nondegenerative, with $\mathrm{A}^{\prime}$ and $\mathrm{A}$ " symmetry as indicated above, and usually remain Infrared and Raman active. The $\mathrm{COOH}$ has 9 internal vibrations modes given by $3 m-3$, where $m$ is the number of atoms in the group. These modes correspond to $\mathrm{O}-\mathrm{H}$ stretching, $\mathrm{C}-\mathrm{O}$ stretching, $\quad \mathrm{C}=\mathrm{O} \quad$ Stretching, in-plane-rocking, in-plane bending of $\mathrm{C}-\mathrm{O}$, in-plane bending of $\mathrm{C}=\mathrm{O}$, in-plane-bending of $\mathrm{OH}$, out-of-plane wagging, and out-of-plane torsion.

$\begin{aligned} & \text { Infrared Spectra of hydrate and } \\ & \text { anhydrous compounds } \\ & \text { infrared }\end{aligned}$ spectra re of
The and
$\left.\mathrm{H}_{3} \mathrm{C}_{6} \mathrm{H}_{4} \mathrm{COOH}\right)_{3} \mathrm{H}_{2} \mathrm{P}_{3} \mathrm{O}_{10} \cdot 3 \mathrm{H}_{2} \mathrm{O}$
$\left.\mathrm{H}_{3} \mathrm{C}_{6} \mathrm{H}_{4} \mathrm{COOH}\right)_{3} \mathrm{H}_{2} \mathrm{P}_{3} \mathrm{O}_{10}$ compounds, recorded the
ge $4000-400 \mathrm{~cm}^{-1}$, are given in Figures $1 \mathrm{a}$ and $1 \mathrm{~b}$.
sese compounds consist of $\mathrm{NH}_{3}^{+}$groups, COOH;

para-substituted benzene ring, $\mathrm{H}_{2} \mathrm{P}_{3} \mathrm{O}_{10}$, and $3 \mathrm{H}_{2} \mathrm{O}$ in the case of hydrate compound.

* $\mathrm{NH}_{3}{ }^{+}$vibrations: Generally, the antisymmetric and symmetric stretching modes of the $\mathrm{NH}_{3}{ }^{+}$group appear in the spectral region of $3200-2800 \mathrm{~cm}^{-1}$ spectral region; whereas the antisymmetric and symmetric deformations appear in the $1660-1610 \mathrm{~cm}^{-}$ ${ }^{1}$ and 1550-1480 $\mathrm{cm}^{-1}$ regions, respectively. In the Infrared spectrum of the anhydrous compound, the $v_{\text {as }}$ $\left(\mathrm{NH}_{3}{ }^{+}\right)$stretching is observed as a medium band at $3230 \mathrm{~cm}^{-1}$. The $v_{\mathrm{s}}\left(\mathrm{NH}_{3}{ }^{+}\right)$stretching modes give a weak and broad band at $2880 \mathrm{~cm}^{-1}$ in the case of the anhydrous compound and a medium band at $2887 \mathrm{~cm}^{-}$ ${ }^{1}$ for the hydrated compound. The remaining bands corresponding to wagging $\mathrm{w}\left(\mathrm{NH}_{3}{ }^{+}\right)$, twisting $\mathrm{t}\left(\left(\mathrm{NH}_{3}{ }^{+}\right)\right.$ and rooking $\rho\left(\mathrm{NH}_{3}{ }^{+}\right)$bending vibrations are assigned as indicated in Table 3 .

* Carboxyl groups vibrations: Studying vibrational spectra of benzoic acid, Antony et al. ${ }^{18}$ assigned $\mathrm{C}=\mathrm{O}, \mathrm{C}-\mathrm{O}$ stretching modes; $\mathrm{C}-\mathrm{O}, \mathrm{C}=\mathrm{O}$ in-plane bending, $\mathrm{OH}$ stretching, rocking mode, torsion mode and wagging mode to band appearing respectively at $1745 \mathrm{~cm}^{-1}, 1050 \mathrm{~cm}^{-1}, 594 \mathrm{~cm}^{-1}, 1804$ $\mathrm{cm}^{-1}, 3785 \mathrm{~cm}^{-1}, 554 \mathrm{~cm}^{-1}, 594 \mathrm{~cm}^{-1}$ and $441 \mathrm{~cm}^{-1}$. Florio et al. ${ }^{19}$ observed $\mathrm{C}=\mathrm{O}$ stretching at $1752 \mathrm{~cm}^{-1}$, $\mathrm{C}-\mathrm{O}$ stretching at $1347 \mathrm{~cm}^{-1}, \mathrm{C}-\mathrm{O}$ in-plane bending at $628 \mathrm{~cm}^{-1}, \mathrm{OH}$ stretch at $3785 \mathrm{~cm}^{-1}$, rocking mode at $628 \mathrm{~cm}^{-1}$, and wagging mode at $160 \mathrm{~cm}^{-1}$. In the present study, the assignment of bands corresponding to the different $\mathrm{COOH}$ vibrations is shown in Table 3. 
* Para substituted benzene ring vibrations: The $\mathrm{C}-\mathrm{H}$ stretching modes of benzene ring are generally expected in the $3115-3005 \mathrm{~cm}^{-1} 20,21$. The $\beta(\mathrm{C}-\mathrm{H})$ "in-plane" and $\delta(\mathrm{C}-\mathrm{H})$ "out-plane" bending vibrations are located in the range $1250-1000 \mathrm{~cm}^{-1}$ and 900-690 $\mathrm{cm}^{-1}$, respectively ${ }^{21,22}$. For the studied compounds, the $\beta(\mathrm{C}-\mathrm{H})$ and $\delta(\mathrm{C}-\mathrm{H})$ of the benzene ring are observed in the expected ranges, as indicated in Table 3. The $\mathrm{C}=\mathrm{C}$ and $\mathrm{C}-\mathrm{C}$ benzene ring stretching modes occur in the $1650-1430 \mathrm{~cm}^{-1}$ and $1400-1300 \mathrm{~cm}^{-1}$, regions respectively 20, 21. For the two compounds, these modes are assigned to the corresponding bands as illustrated in Table 3. Finally, the $\mathrm{C}-\mathrm{N}$ stretching and the ring breathing modes were identified for the studied compounds and given in Table 3.

* $\mathrm{H}_{2} \mathrm{P}_{3} \mathrm{O}_{10}{ }^{3-}$ vibrations: The assignment of bands due to the fundamental modes, valence and bending, of $\mathrm{P}_{3} \mathrm{O}_{10}{ }^{5-}$ anions are presented in Table 3 for both triphosphates. The frequencies of the $\mathrm{P}_{3} \mathrm{O}_{10}{ }^{5-}$ anion are assigned based on the characteristic vibrations of the $\mathrm{P}-\mathrm{O}-\mathrm{P}$ bridge, $\mathrm{PO}_{2}$ and $\mathrm{PO}_{3}$ groups. Since the $\mathrm{P}-\mathrm{O}$ bond in the $\mathrm{PO}_{2}$ and $\mathrm{PO}_{3}$ group is weaker than that in the

$\mathrm{P}-\mathrm{O}-\mathrm{P}$ Bridge, the vibrational frequencies of $\mathrm{PO}_{2}$ and $\mathrm{PO}_{3}$ are expected to be higher than those for $\mathrm{P}-\mathrm{O}-\mathrm{P}$. The bands due to the symmetric and antisymmetric stretching frequencies of $\mathrm{PO}_{2}$ and $\mathrm{PO}_{3}$ in $\mathrm{P}_{3} \mathrm{O}_{10}{ }^{5-}$ are generally observed in the region $1190-1010 \mathrm{~cm}^{-122,23}$. The bands observed in the domain $970-840 \mathrm{~cm}^{-1}$ are attributed to the antisymmetric and symmetric POP stretching modes. The bands due to $\delta(\mathrm{OPO}), \delta\left(\mathrm{PO}_{2}\right)$, $\delta\left(\mathrm{PO}_{3}\right)$ and $\delta(\mathrm{POP})$ are also identified in Table 3 , which contains the IR frequencies and the vibrational modes corresponding to $\mathrm{Rb}_{3} \mathrm{H}_{2} \mathrm{P}_{3} \mathrm{O}_{10} .1,5 \mathrm{H}_{2} \mathrm{O}$, paracarboxyphenylammonium $\quad \mathrm{NH}_{2} \mathrm{C}_{6} \mathrm{H}_{4} \mathrm{COOH}$, compared with those of $\left(\mathrm{NH}_{3} \mathrm{C}_{6} \mathrm{H}_{4} \mathrm{COOH}\right)_{3} \mathrm{H}_{2} \mathrm{P}_{3} \mathrm{O}_{10} .3 \mathrm{H}_{2} \mathrm{O}$ and $\left(\mathrm{NH}_{3} \mathrm{C}_{6} \mathrm{H}_{4} \mathrm{COOH}\right)_{3} \mathrm{H}_{2} \mathrm{P}_{3} \mathrm{O}_{10}$. The IR frequencies of the $\mathrm{P}_{3} \mathrm{O}_{10}{ }^{5-}$ anions observed in the two triphosphates associated to para carboxyphenylammonium, $\left(\mathrm{NH}_{3} \mathrm{C}_{6} \mathrm{H}_{4} \mathrm{COOH}\right)_{3} \mathrm{H}_{2} \mathrm{P}_{3} \mathrm{O}_{10} .3 \mathrm{H}_{2} \mathrm{O}$ and $\left(\mathrm{NH}_{3} \mathrm{C}_{6} \mathrm{H}_{4} \mathrm{COOH}\right)_{3} \mathrm{H}_{2} \mathrm{P}_{3} \mathrm{O}_{10}$, are the same as those observed in the triphosphate associated to rubidium $\mathrm{Rb}_{3} \mathrm{H}_{2} \mathrm{P}_{3} \mathrm{O}_{10} \cdot 1,5 \mathrm{H}_{2} \mathrm{O}^{22}$

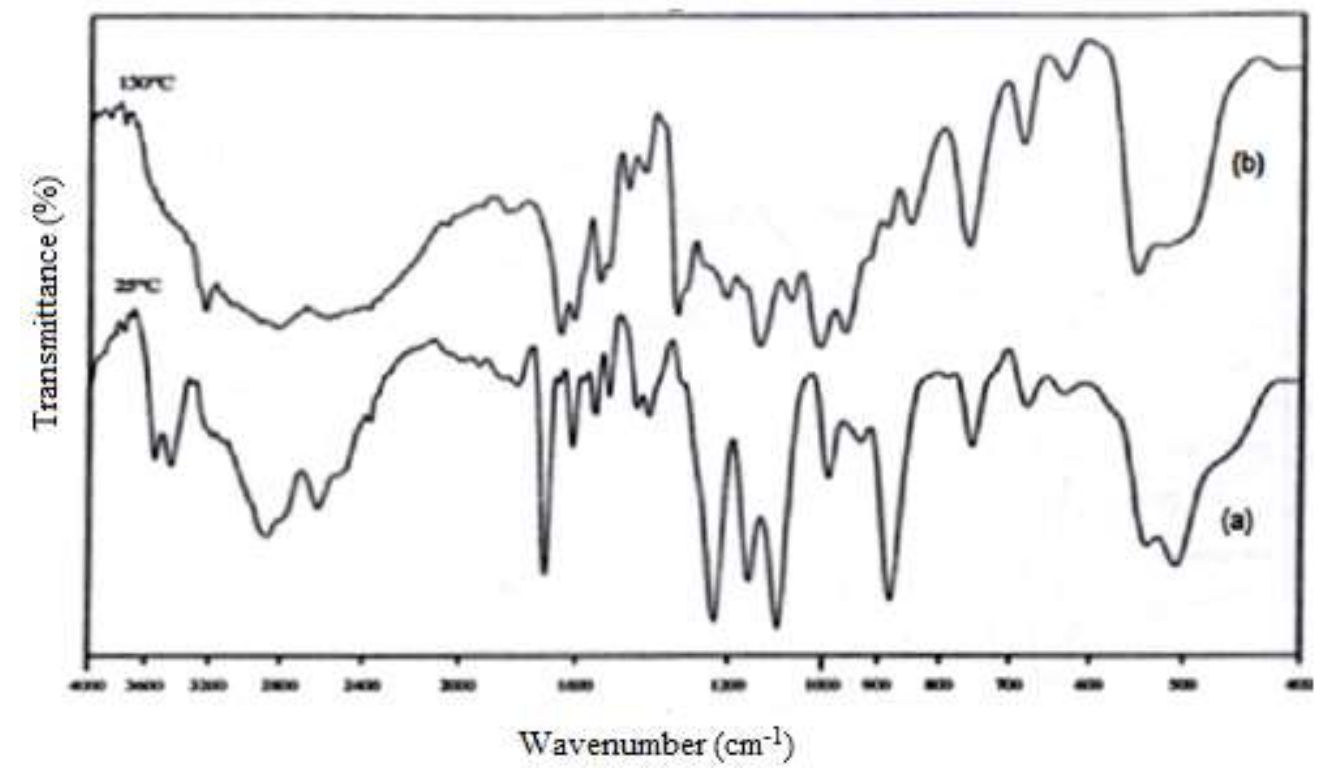

Figure 1. IR spectra of the phosphates: (a) $\left(\mathrm{NH}_{3} \mathrm{C}_{6} \mathrm{H}_{4} \mathrm{COOH}\right)_{3} \mathrm{H}_{2} \mathrm{P}_{3} \mathrm{O}_{10} .3 \mathrm{H}_{2} \mathrm{O}$ and (b) $\left(\mathrm{NH}_{3} \mathrm{C}_{6} \mathrm{H}_{4} \mathrm{COOH}\right)_{3} \mathrm{H}_{2} \mathrm{P}_{3} \mathrm{O}_{10}$

Table 3. Characterization of $\left(\mathrm{NH}_{3} \mathrm{C}_{6} \mathrm{H}_{4} \mathrm{COOH}\right)_{3} \mathrm{H}_{2} \mathrm{P}_{3} \mathrm{O}_{10} .3 \mathrm{H}_{2} \mathrm{O}$ and $\left(\mathrm{NH}_{3} \mathrm{C}_{6} \mathrm{H}_{4} \mathrm{COOH}\right)_{3} \mathrm{H}_{2} \mathrm{P}_{3} \mathrm{O}_{10}$ by IR vibration spectrometry ${ }^{6,12,13}$.

\begin{tabular}{|c|c|c|c|c|}
\hline $\mathrm{Rb}_{3} \mathrm{H}_{2} \mathrm{P}_{3} \mathrm{O}_{10} \cdot 1,5 \mathrm{H}_{2} \mathrm{O}$ & $\mathrm{NH}_{2} \mathrm{C}_{6} \mathrm{H}_{4} \mathrm{COOH}$ & $\left(\mathrm{NH}_{3} \mathrm{C}_{6} \mathrm{H}_{4} \mathrm{COOH}\right)_{3} \mathrm{H}_{2} \mathrm{P}_{3} \mathrm{O}_{10} .3 \mathrm{H}_{2} \mathrm{O}$ & $\left(\mathrm{NH}_{3} \mathrm{C}_{6} \mathrm{H}_{4} \mathrm{COO}\right)_{3} \mathrm{H}_{2} \mathrm{P}_{3} \mathrm{O}_{10}$ & Vibrational modes \\
\hline 3553 & & 3545 & & \multirow{4}{*}{$\begin{array}{l}v(\mathrm{OH}) \\
v_{\text {as }}\left(\mathrm{NH}_{3}{ }^{+}\right) \\
v_{\text {as }}\left(\mathrm{NH}_{3}{ }^{+}\right)\end{array}$} \\
\hline \multirow[t]{6}{*}{3428} & 3466 & 3449 & & \\
\hline & 3367 & & & \\
\hline & 3233 & & 3230 & \\
\hline & 3065 & & & $v(\mathrm{OH})+v(\mathrm{C}-\mathrm{H})$ \\
\hline & 2980 & 2885 & 2880 & \multirow{4}{*}{$\begin{array}{l}v_{\mathrm{S}}\left(\mathrm{NH}_{3}^{+}\right) \\
\text {Non-fundamental } \\
\text { modes }\end{array}$} \\
\hline & & & & \\
\hline \multirow[t]{2}{*}{2730} & & & 2780 & \\
\hline & 2678 & 2614 & 2577 & \\
\hline
\end{tabular}




\begin{tabular}{|c|c|c|c|c|}
\hline 2350 & 2552 & & 2390 & \multirow[b]{4}{*}{$\beta C=O$ in-plane } \\
\hline & & & 2036 & \\
\hline & 1912 & & & \\
\hline & & & 1846 & \\
\hline \multirow{11}{*}{1770} & & & & \multirow{9}{*}{$\begin{array}{l}\delta(\mathrm{OH}) / v \mathrm{C}=\mathrm{O} \\
\delta_{\mathrm{as}} \mathrm{NH}_{3}{ }^{+} / v \mathrm{C}=\mathrm{C} / v \\
\mathrm{C}=\mathrm{O} \\
\delta_{\mathrm{s}} \mathrm{NH}_{3}{ }^{+} / v \mathrm{C}=\mathrm{C} \\
\delta_{\mathrm{s}} \mathrm{NH}_{3}{ }^{+} / v \mathrm{C}=\mathrm{C} \\
v \mathrm{C}=\mathrm{C} \\
v \mathrm{C}-\mathrm{N} / \beta(\mathrm{OH}) \\
v \mathrm{C}-\mathrm{N} / \beta(\mathrm{OH})\end{array}$} \\
\hline & 1673 & 1698 & & \\
\hline & 1632 & & & \\
\hline & 1602 & 1614 & 1600 & \\
\hline & 1580 & 1578 & 1561 & \\
\hline & 1532 & 1550 & 1539 & \\
\hline & & 1510 & 1516 & \\
\hline & 1441 & 1431 & 1468 & \\
\hline & 1420 & 1403 & 1424 & \\
\hline & 1321 & 1317 & 1341 & \multirow{2}{*}{$\begin{array}{l}v \mathrm{C}-\mathrm{C} / v \mathrm{C}-\mathrm{N} / v \mathrm{C}- \\
\mathrm{O}\end{array}$} \\
\hline & 1293 & & & \\
\hline 1233 & & 1237 & & \multirow{3}{*}{$\begin{array}{l}v \mathrm{C}-\mathrm{O} / \beta(\mathrm{C}-\mathrm{H}) / \beta(\mathrm{P}- \\
\mathrm{OH})\end{array}$} \\
\hline \multicolumn{4}{|l|}{1203} & \\
\hline \multirow{2}{*}{1191} & 1180 & & 1200 & \\
\hline & & 1156 & & \multirow{6}{*}{$\begin{array}{l}\beta(\mathrm{C}-\mathrm{H}) / \nu(\mathrm{P}=\mathrm{O}) \\
\beta(\mathrm{C}-\mathrm{H}) / \rho\left(\mathrm{NH}_{3}{ }^{+}\right) \\
\beta(\mathrm{C}-\mathrm{H}) / \rho\left(\mathrm{NH}_{3}{ }^{+}\right) \\
\beta(\mathrm{C}-\mathrm{H}) \\
\beta(\mathrm{C}-\mathrm{H}) / \nu \mathrm{C}-\mathrm{O}\end{array}$} \\
\hline 1126 & 1131 & & 1130 & \\
\hline 1101 & & 1096 & & \\
\hline & 1075 & & 1060 & \\
\hline \multirow{5}{*}{$\begin{array}{l}1032 \\
1000\end{array}$} & & & & \\
\hline & 970 & 997 & 1000 & \\
\hline & 920 & 934 & 953 & \multirow{6}{*}{$\begin{array}{l}\mathrm{w}\left(\mathrm{NH}_{3}{ }^{+}\right) / v \mathrm{PO}_{2} \\
v \mathrm{PO}_{3} \\
\delta(\mathrm{C}-\mathrm{H}) \\
v \mathrm{P}-\mathrm{O}-\mathrm{P} / \text { Ring } \\
\text { breathing } \\
\mathrm{t}\left(\mathrm{NH}_{3}^{+}\right) / \delta(\mathrm{C}-\mathrm{H})\end{array}$} \\
\hline & 899 & 883 & 890 & \\
\hline & 843 & & 845 & \\
\hline & 773 & 761 & 756 & \\
\hline 714 & 709 & 727 & & \\
\hline \multirow[t]{5}{*}{684} & & 686 & 678 & \\
\hline & & & & $\delta(\mathrm{C}-\mathrm{H})$ \\
\hline & 618 & 637 & & \multirow{3}{*}{$\begin{array}{l}\text { v C=O } \\
\rho \mathrm{CO}_{2} / v \mathrm{PO}_{4} \\
\delta \mathrm{PO}_{2}\end{array}$} \\
\hline & 555 & 542 & 540 & \\
\hline & 498 & 511 & & \\
\hline
\end{tabular}

\section{Study of the thermal behavior of $\left(\mathrm{NH}_{4}\right)_{3} \mathrm{P}_{3} \mathrm{O} 9$}

To facilitate the thermal behavior study of $\left(\mathrm{NH}_{3} \mathrm{C}_{6} \mathrm{H}_{4} \mathrm{COOH}\right)_{3} \mathrm{H}_{2} \mathrm{P}_{3} \mathrm{O}_{10} .3 \mathrm{H}_{2} \mathrm{O}$, we firstly studied the decomposition of $\left(\mathrm{NH}_{4}\right)_{3} \mathrm{P}_{3} \mathrm{O}_{9}$, which was prepared by the method of ion-exchange resin ${ }^{9}$, and characterized crystallographically by M. BagieuBeucher in $1976{ }^{23}$. It crystallizes in the monoclinic system with space group $\mathrm{P} 2{ }_{1} / \mathrm{n}(\mathrm{Z}=4)\left(\mathrm{C}_{2 \mathrm{~h}}{ }^{5}\right)$, and parameters: $\mathrm{a}=11,515 \AA, \mathrm{b}=12,206 \AA, \mathrm{c}=7.699 \AA$, $\beta=101.63^{\circ}$. The structure of $\left(\mathrm{NH}_{4}\right)_{3} \mathrm{P}_{3} \mathrm{O}_{9}$ was resolved using that of its isotype $\mathrm{K}_{3} \mathrm{P}_{3} \mathrm{O}_{9}{ }^{23}$. In this structure, the $\mathrm{P}_{3} \mathrm{O}_{9}$ cycle does not have proper symmetry. Its $C_{1}$ symmetry is approximately $C_{3 v}$, where $\mathrm{k}^{+}$cations or $\mathrm{NH}_{4}{ }^{+}$occupy three separate sites.

Indeed, we have prepared $\left(\mathrm{NH}_{4}\right)_{3} \mathrm{P}_{3} \mathrm{O}_{9}$ by the exchange resin method and controlled its purity by $\mathrm{X}$-ray diffraction, and then we examine the thermal behavior, between 25 and $1400^{\circ} \mathrm{C}$ (sample mass: 23 $\mathrm{mg}$ ) using the coupled TG-DTA analyses with a heating rate of $1{ }^{\circ} \mathrm{C} / \mathrm{min}$. TGA, DTA and DTG curves
(Figures 2 and 3) show two distinct steps. The first step between $180^{\circ} \mathrm{C}$ and $450^{\circ} \mathrm{C}$ corresponds to a loss in brutal mass $17.5 \%$. This loss is the equivalent of three ammonia molecules per formula unit. The DTG curve indicates two distinct peaks, the first at $180{ }^{\circ} \mathrm{C}$ and the second at $295^{\circ} \mathrm{C}$. However, the elimination of the first molecule of $\mathrm{NH}_{3}$ does not seem to be accompanied by a thermal effect. For the other two molecules of $\mathrm{NH}_{3}$, the DTA curve indicates a peak, endothermic top temperature to $290^{\circ} \mathrm{C}$, which is of asymmetrical profile. This confirms the existence of more than one type of site occupied by $\mathrm{NH}_{4}{ }^{+}$in the structure of $\left(\mathrm{NH}_{4}\right)_{3} \mathrm{P}_{3} \mathrm{O}_{9}$. Moreover, explains the succeeding departure of 3 molecules of $\mathrm{NH}_{3}$ because of distinct bond energies. At $450^{\circ} \mathrm{C}$, after the departure of 3 ammonia molecules per formula unit and a thermal residue, $240 \mathrm{~g} / \mathrm{mol}$, destroyed $\left(\mathrm{NH}_{4}\right)_{3} \mathrm{P}_{3} \mathrm{O}_{9}$ and leads to $\mathrm{H}_{3} \mathrm{P}_{3} \mathrm{O}_{9}$. The reaction scheme is the following: 


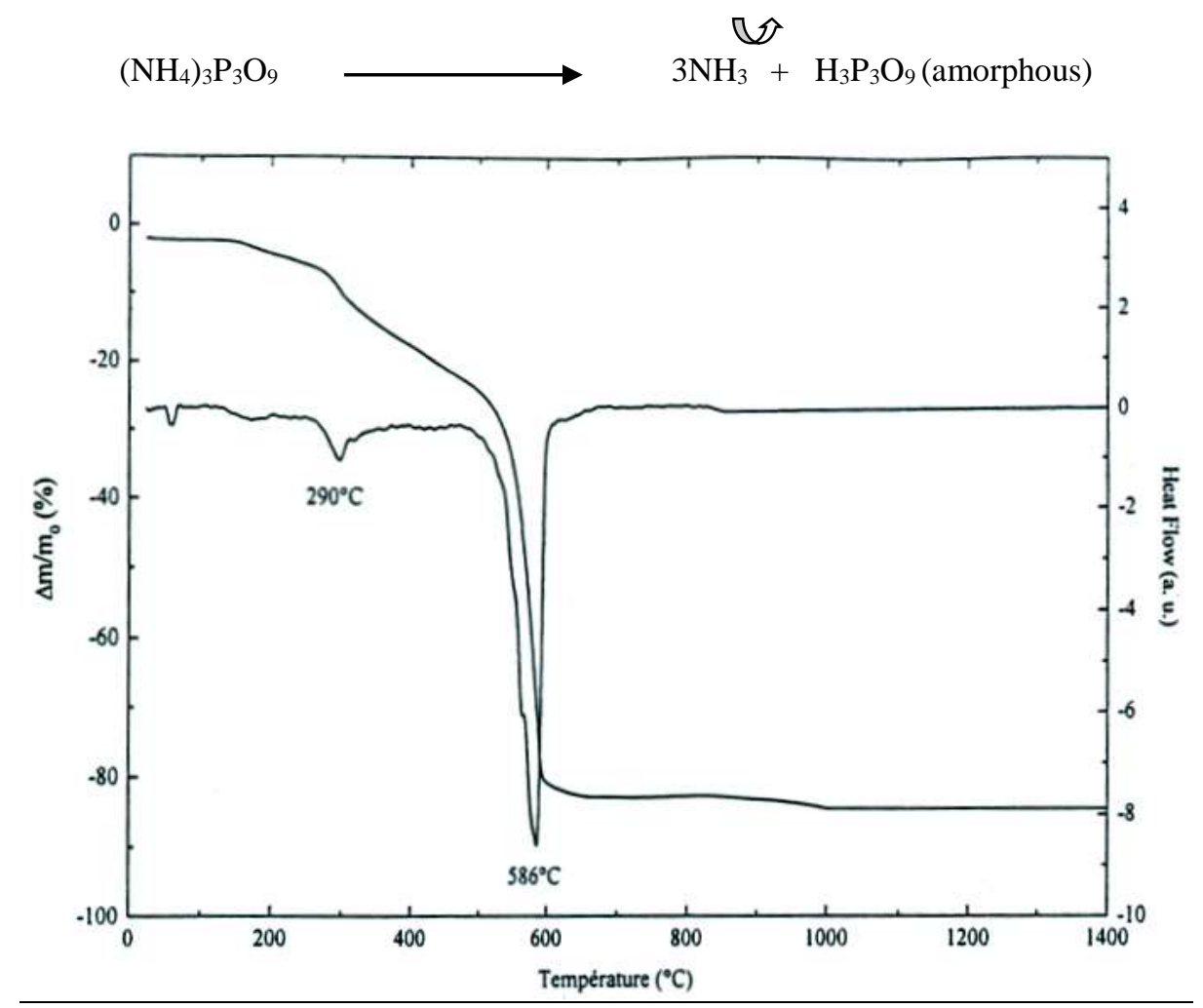

Figure 2. TGA-DTA thermograms of $\left(\mathrm{NH}_{4}\right)_{3} \mathrm{P}_{3} \mathrm{O}_{9}\left(\mathrm{~V}=1^{\circ} \mathrm{C} / \mathrm{min}\right)$.

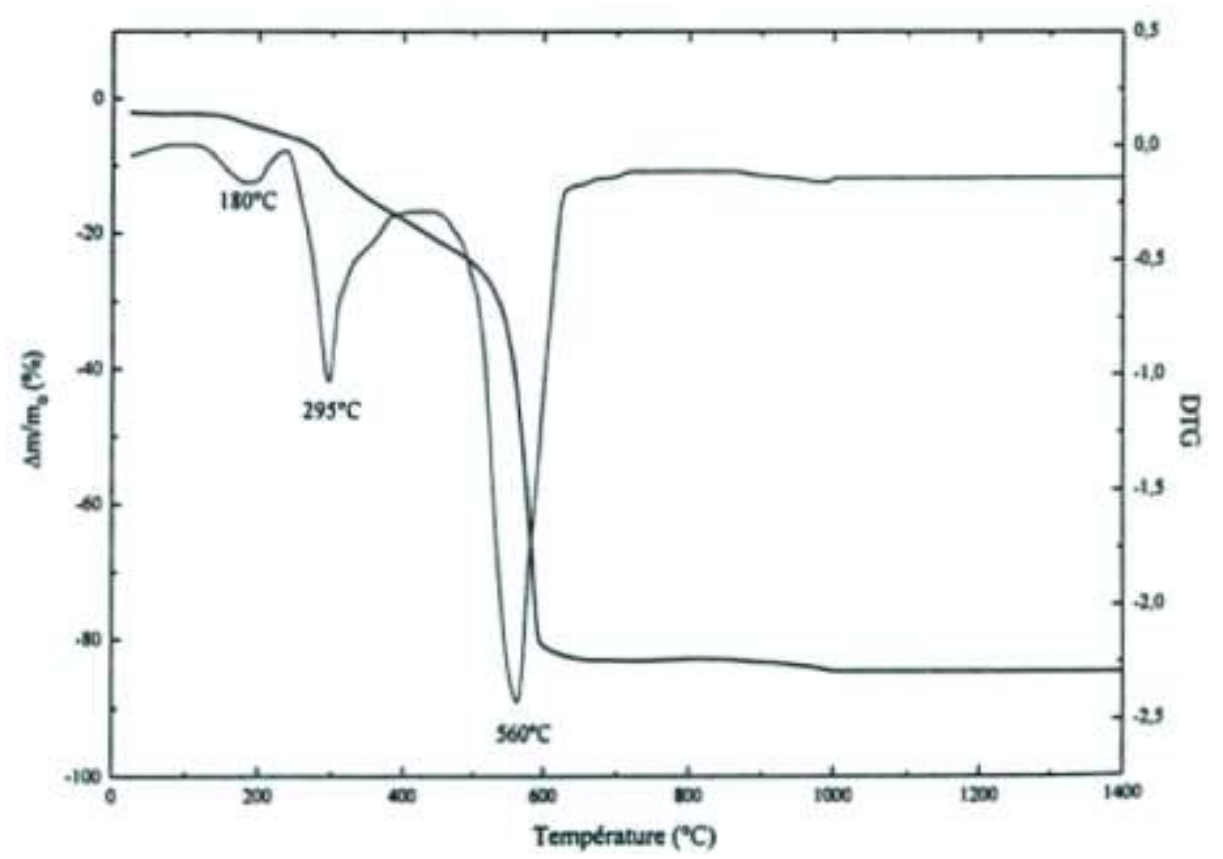

Figure 3. TG-DTG thermograms of $\left(\mathrm{NH}_{4}\right)_{3} \mathrm{P}_{3} \mathrm{O}_{9}\left(\mathrm{~V}=1^{\circ} \mathrm{C} / \mathrm{min}\right)$

The second stage, between $450^{\circ} \mathrm{C}$ and $650^{\circ} \mathrm{C}$, corresponds to a weight loss of $64.5 \%$, the equivalent of $2 / 3$ of the weight of thermal residue $\mathrm{H}_{3} \mathrm{P}_{3} \mathrm{O}_{9}$. This loss is accompanied by an intense and endothermic
DTA peak at $586^{\circ} \mathrm{C}$ due to the decomposition of the acid $\mathrm{H}_{3} \mathrm{P}_{3} \mathrm{O}_{9}$ amorphous entity which releases $\mathrm{H}_{2} \mathrm{O}$ and $\mathrm{P}_{2} \mathrm{O}_{5}$ with a top speed at $560^{\circ} \mathrm{C}$ on the DTG curve. At $650^{\circ} \mathrm{C}$, the reaction scheme is the following:

$$
\stackrel{0}{0}
$$

Between $650^{\circ} \mathrm{C}$ and $1400^{\circ} \mathrm{C}$, any mass loss was observed in the TGA thermogram, and any thermal effect was highlighted by the TGA-DTA thermograms (Figure 2). 


\section{Study of the thermal behavior of $\left(\mathrm{NH}_{3} \mathrm{C}_{6} \mathrm{H}_{4} \mathrm{COOH}\right)_{3} \mathrm{H}_{2} \mathrm{P}_{3} \mathrm{O}_{10.3 \mathrm{H}_{2} \mathrm{O}}$}

The study of the thermal behavior of tetra (4-carboxyphenyl ammonium) dihydrogenotriphosphate trihydrate $\left(\mathrm{NH}_{3} \mathrm{C}_{6} \mathrm{H}_{4} \mathrm{COOH}\right)_{3} \mathrm{H}_{2} \mathrm{P}_{3} \mathrm{O}_{10} .3 \mathrm{H}_{2} \mathrm{O}$, was performed by linear increase in temperature from 25 to $600^{\circ} \mathrm{C}$ using the TGA coupled on thermodifferential of powder samples of about $20 \mathrm{mg}$, at different heating rates: $\mathrm{v}=$ $1,3,6,10$ and $15^{\circ} \mathrm{C} / \mathrm{min}$ under atmospheric pressure.

\section{Thermogravimetric analysis}

The TGA thermograms of $\left(\mathrm{NH}_{3} \mathrm{C}_{6} \mathrm{H}_{4} \mathrm{COOH}\right)_{3} \mathrm{H}_{2} \mathrm{P}_{3} \mathrm{O}_{10} .3 \mathrm{H}_{2} \mathrm{O}$, realized at different heating rates (Figure 4 ), have all the same look and show five separate mass loss steps. Careful examination of the thermograms, carried out at low speed, indicates that the first step is not on that initially the water whereas the other four steps are related to entities from the decomposition of the organic matrix and the mineral matrix.

The TGA-DTA thermogram realized at a heating rate of $3^{\circ} \mathrm{C} / \mathrm{min}$ (Figure 5) shows 5 mass loss steps:

- The first stage begins at $110^{\circ} \mathrm{C}$ and ends at $126^{\circ} \mathrm{C}$. It appears to involve a single process of evolving water (mass loss calculated $7.47 \%$, observed $7.5 \%$ ). The
DTG thermogram has a maximum loss of water at $118^{\circ} \mathrm{C}$.

Between 126 and $168^{\circ} \mathrm{C}$, in the TGA thermogram, there is no variation of mass.

- The second step starts at $168^{\circ} \mathrm{C}$ and ends at $188^{\circ} \mathrm{C}$. It corresponds to a mass loss, relatively fast, about $7.01 \%$. It is attributed to the loss of three molecules of ammonia for which the loss mass is theoretically calculated of $7.05 \%$. The maximum loss is observed on the DTG thermogram at $179^{\circ} \mathrm{C}$.

- The third stage, between 188 and $260^{\circ} \mathrm{C}$, corresponding to a mass loss of $18.22 \%$, is assigned to 3 moles of $\mathrm{CO}_{2}$ per formula unit (mass loss calculated $18.2 \%$ ). Two loss maxima are reported on the DTG curve, during the third step, the first peak well pronounced at $197^{\circ} \mathrm{C}$ and a second peak doubtful to $214^{\circ} \mathrm{C}$.

- The fourth step starts at 260 and ends at $310^{\circ} \mathrm{C}$. It corresponds to a weight loss of $13.4 \%$ and could be attributed to the loss of gas from the decomposition of the residual heat. The maximum rate of loss is observed on the DTG thermogram at $280^{\circ} \mathrm{C}$.

- The fifth stage, between 310 and $530^{\circ} \mathrm{C}$, corresponding to a mass loss of $20.9 \%$. This loss could be attributed to the combustion of the organic matrix.

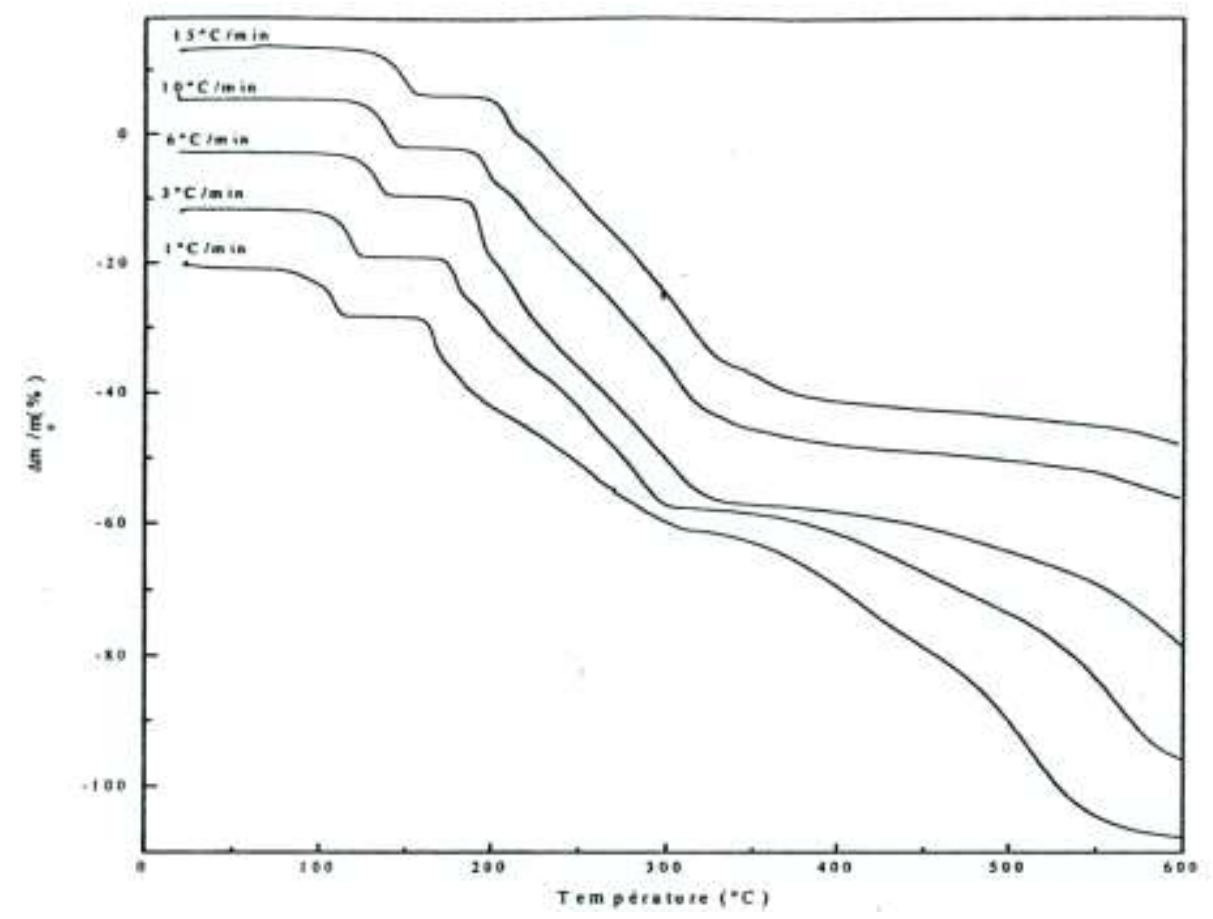

Figure 4. TGA thermograms of $\left(\mathrm{NH}_{3} \mathrm{C}_{6} \mathrm{H}_{4} \mathrm{COOH}\right)_{3} \mathrm{H}_{2} \mathrm{P}_{3} \mathrm{O}_{10} .3 \mathrm{H}_{2} \mathrm{O}$ at different heating rates. 


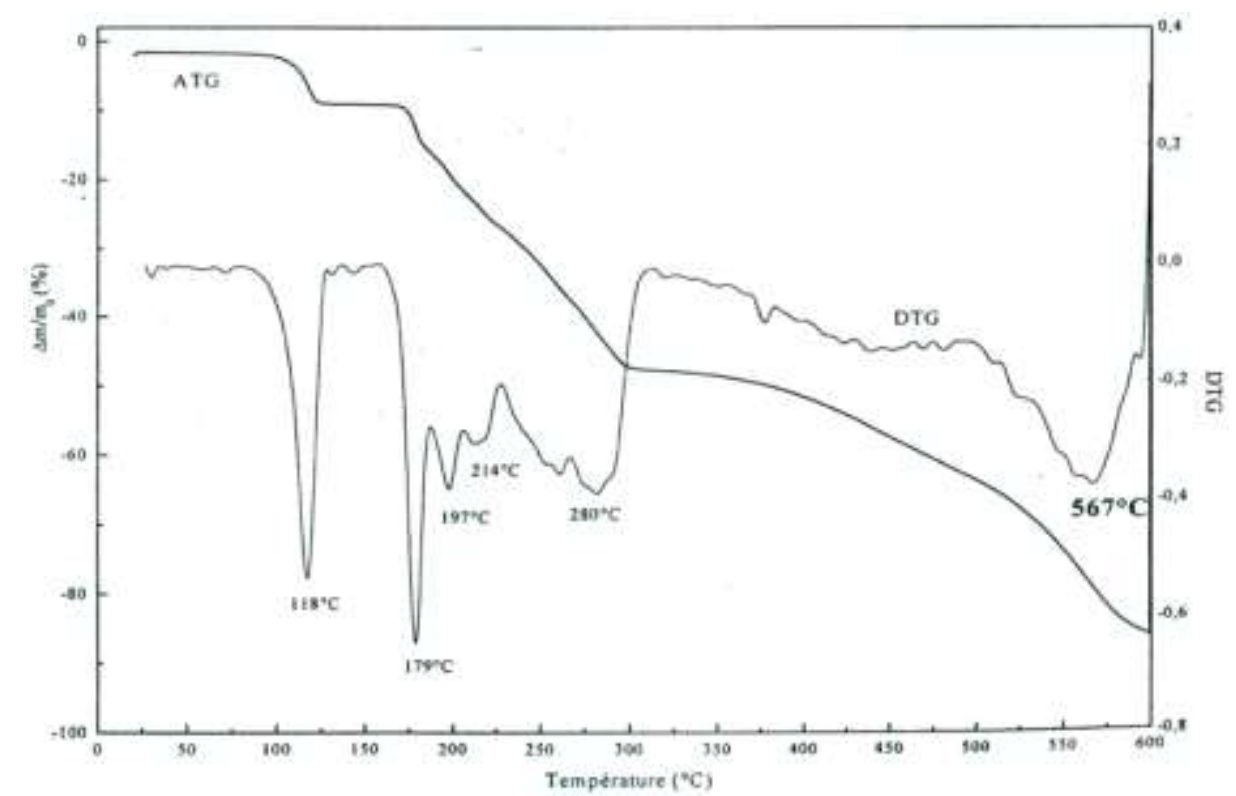

Figure 5. TG-DTG thermograms of $\left(\mathrm{NH}_{3} \mathrm{C}_{6} \mathrm{H}_{4} \mathrm{COOH}\right)_{3} \mathrm{H}_{2} \mathrm{P}_{3} \mathrm{O}_{10} \cdot 3 \mathrm{H}_{2} \mathrm{O}$ at $3{ }^{\circ} \mathrm{C} / \mathrm{min}$.

- The sixth stage, between 530 and $600^{\circ} \mathrm{C}$, corresponding to a weight loss of $17 \%$, is accompanied by a DTG peak at $567^{\circ} \mathrm{C}$ corresponding to the maximum speed of water $\mathrm{H}_{2} \mathrm{O}$ and pentaoxide phosphorus $\mathrm{P}_{2} \mathrm{O}_{5}$ release from the decomposition of the mineral matrix.

\section{Differential thermal analysis}

DTA thermograms made at different speeds and coupled with the thermogravimetric analysis are

$$
\left(\mathrm{NH}_{3} \mathrm{C}_{6} \mathrm{H}_{4} \mathrm{COOH}\right)_{3} \mathrm{H}_{2} \mathrm{P}_{3} \mathrm{O}_{10} \cdot 3 \mathrm{H}_{2} \mathrm{O} \longrightarrow\left(\mathrm{NH}_{3} \mathrm{C}_{6} \mathrm{H}_{4} \mathrm{COOH}\right)_{3} \mathrm{H}_{2} \mathrm{P}_{3} \mathrm{O}_{10}+3 \mathrm{H}_{2} \mathrm{O}
$$

An exothermic peak was observed at $147^{\circ} \mathrm{C}$ only for the weak heating rates for 1 and $3^{\circ} \mathrm{C} / \mathrm{min}$ after the total removal of water. It corresponds to the crystallization of the corresponding anhydrous $\left(\mathrm{NH}_{3} \mathrm{C}_{6} \mathrm{H}_{4} \mathrm{COOH}\right)_{3} \mathrm{H}_{2} \mathrm{P}_{3} \mathrm{O}_{10}$. This wellcrystallized phase was characterized by its IR spectrum (Figure 1).

- The second stage, between 168 and $188^{\circ} \mathrm{C}$, is accompanied by two endothermic peaks at 174 and $180^{\circ} \mathrm{C}$. The last peak at $180^{\circ} \mathrm{C}$ coincides with the maximum loss at $179^{\circ} \mathrm{C}$. These two endothermic

$$
\left(\mathrm{NH}_{3} \mathrm{C}_{6} \mathrm{H}_{4} \mathrm{COOH}\right)_{3} \mathrm{H}_{2} \mathrm{P}_{3} \mathrm{O}_{10}
$$

- The third stage, between 188 and $260^{\circ} \mathrm{C}$, corresponding to the departure of 3 moles of $\mathrm{CO}_{2}$, is accompanied by an endothermic peak at $197^{\circ} \mathrm{C}$ which coincides with the maximum loss rep orted on the DTG curve peak at $197^{\circ} \mathrm{C}$. It is worth noticing that this third stage can be subdivided into two distinct stages. The first one is made between 188 and $210^{\circ} \mathrm{C}$, the second between 210 and $260^{\circ} \mathrm{C}$. In this case, the endothermic peak observed at $197^{\circ} \mathrm{C}$ would be the $\mathrm{CO} 2$ group the more weakly bonded to the organic chain shown in Figure 6. The analysis of the thermogram corresponding to the heating rate $3^{\circ} \mathrm{C} / \mathrm{min}$ (Figure 7) allows to highlight the following points:

The first phase, between 110 and $126^{\circ} \mathrm{C}$, accompanied by an endothermic peak at $118^{\circ} \mathrm{C}$, which coincides with the maximum reported loss on the derivative curve at $118^{\circ} \mathrm{C}$. This peak corresponds to the loss of 3 water molecules according to the following reaction scheme:

effects are attributed to the loss of three molecules of ammonia. The presence of two endothermic peaks may be interpreted based on structural data of $\left(\mathrm{NH}_{3} \mathrm{C}_{6} \mathrm{H}_{4} \mathrm{COOH}\right)_{3} \mathrm{H}_{2} \mathrm{P}_{3} \mathrm{O}_{10} .3 \mathrm{H}_{2} \mathrm{O}$, which indicates the presence of three types of nitrogen atoms. The first endothermic peak at $174^{\circ} \mathrm{C}$, can be attributed to the departure of two moles of ammonia $\mathrm{NH}_{3}$ (1) and $\mathrm{NH}_{3}$ (3), the two nitrogen atoms having thermal agitation factors very close 2,7 , and the second at $180^{\circ} \mathrm{C}$, the last remaining ammonia molecule $\mathrm{NH}_{3}$ (2) (having a nitrogen atom of thermal agitation factor low ${ }^{12}$ ). The reaction scheme is as follows:

The endothermic peak observed at $197^{\circ} \mathrm{C}$ is related to the $\mathrm{CO}_{2}$ group, more weakly bonded to the organic chain $\left(\mathrm{CO}_{2}(7)\right)$, and it corresponds to the liberation of $6.06 \%$, the $\mathrm{CO}_{2}$ removed between (1/3) 188 and $210^{\circ} \mathrm{C}(18.02 \%)$. The second stage from $12.1 \%$ per formula unit; (2/3) of $\mathrm{CO}_{2}$ corresponding to groups $\left(\mathrm{CO}_{2}(14)\right)$ and $\left(\mathrm{CO}_{2}(21)\right)$. Indeed, the structure of the compound shows that the $\mathrm{C}_{6}-\mathrm{C}_{7}$ distance is relatively longer, $1.498 \AA$ longer, longer than $1.498 \AA$. The reaction scheme in this step is as follows:

\section{《)}

$$
\left(\mathrm{C}_{7} \mathrm{H}_{5} \mathrm{O}_{2}\right)_{3} \mathrm{H}_{2} \mathrm{P}_{3} \mathrm{O}_{10} \longrightarrow\left(\mathrm{C}_{6} \mathrm{H}_{5}\right)_{3} \mathrm{H}_{2} \mathrm{P}_{3} \mathrm{O}_{10}+3 \mathrm{CO}_{2}
$$


The thermal residue obtained at the end of the third stage $\left(\mathrm{C}_{6} \mathrm{H}_{5}\right)_{3} \mathrm{H}_{2} \mathrm{P}_{3} \mathrm{O}_{10}$ after loss successively of $3 \mathrm{H}_{2} \mathrm{O},\left(2 \mathrm{NH}_{3}, 1 \mathrm{NH}_{3}\right)$ and $3 \mathrm{CO}_{2}$ per formula unit undergoes thermal degradation of organic matrices and mineral. The ATD Thermogram brings up an exothermic peak at around $300^{\circ} \mathrm{C}$, which could be attributed to an atomic reorganization. Indeed, the temperature of the start of the exothermic effect coincides with the onset temperature of the 4th stage and the exothermic peak observed at $300^{\circ} \mathrm{C}$ corresponds to the temperature of the end of this step.

- The fifth stage, between 310 and $530^{\circ} \mathrm{C}$, make appear an exothermic peak at the top temperature of $432^{\circ} \mathrm{C}$, which may be due to the burning of the residue of the organic matrix.

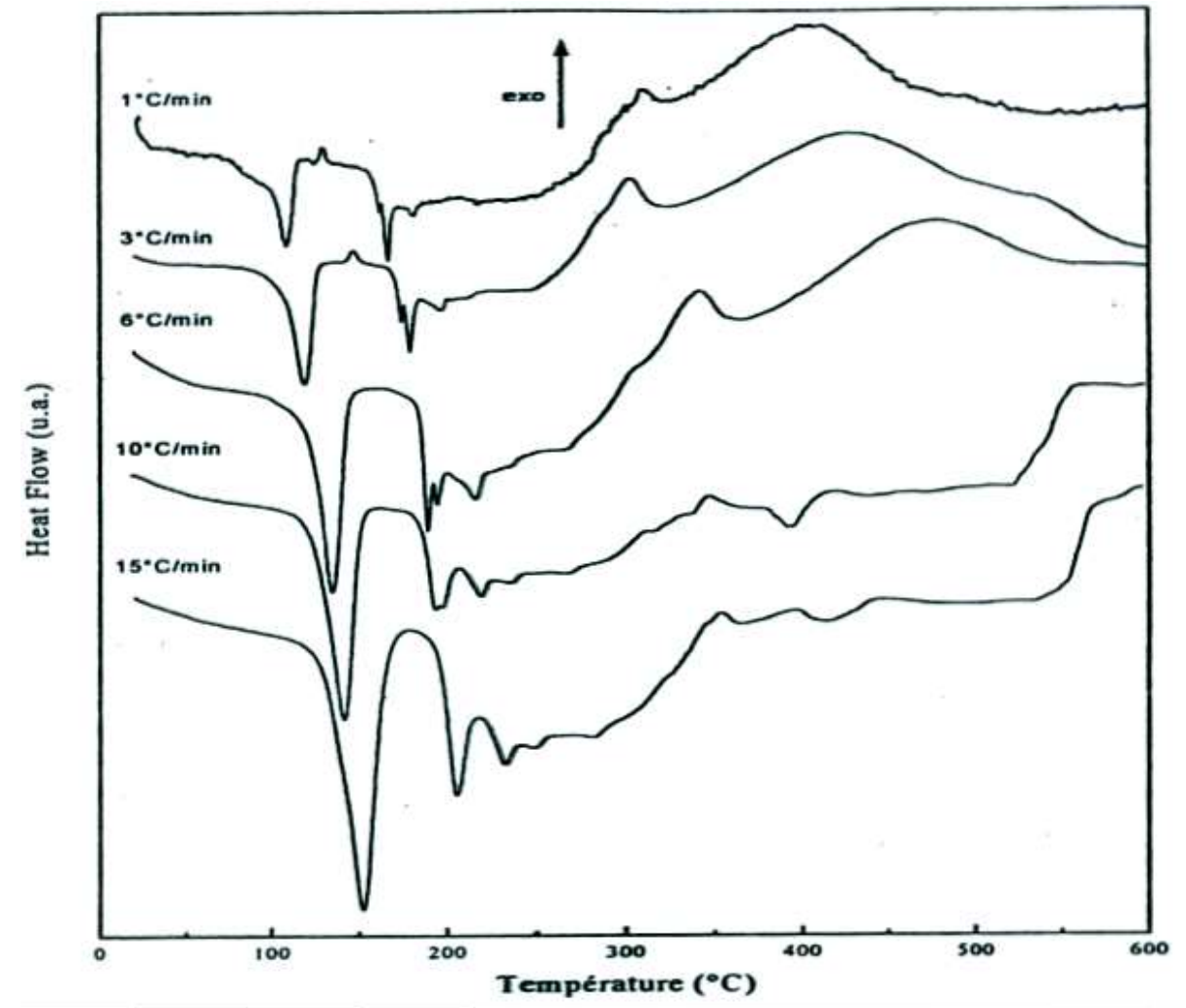

Figure 6. TGA thermograms of $\left(\mathrm{NH}_{3} \mathrm{C}_{6} \mathrm{H}_{4} \mathrm{COOH}\right)_{3} \mathrm{H}_{2} \mathrm{P}_{3} \mathrm{O}_{10} .3 \mathrm{H}_{2} \mathrm{O}$ at different heating rates

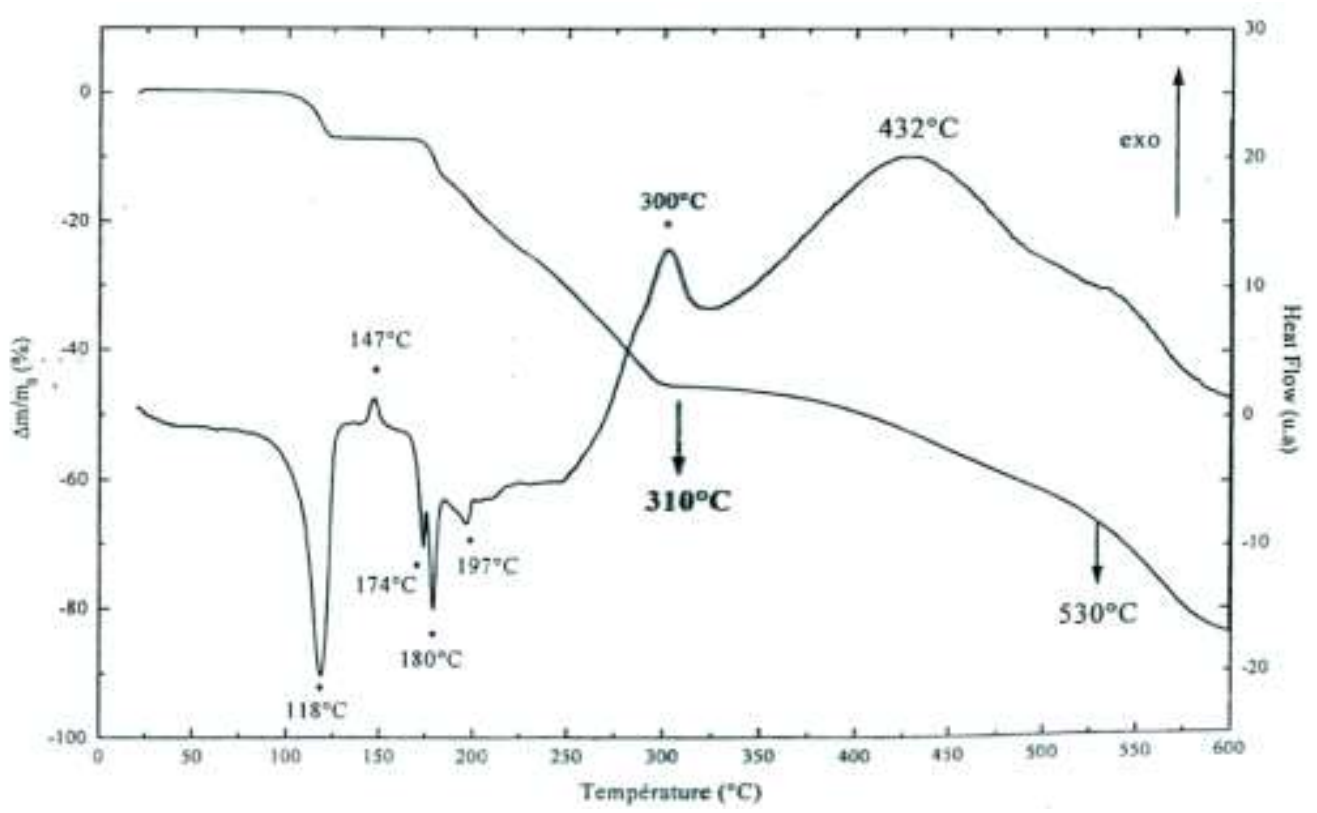

Figure 7. TGA-DTA thermograms of $\left(\mathrm{NH}_{3} \mathrm{C}_{6} \mathrm{H}_{4} \mathrm{COOH}\right)_{3} \mathrm{H}_{2} \mathrm{P}_{3} \mathrm{O}_{10} \cdot 3 \mathrm{H}_{2} \mathrm{O}$ at $3^{\circ} \mathrm{C} / \mathrm{min}$.

Measurement of kinetic parameters

Estimation of the thermodynamic functions: Various equations of kinetic analyses are known ${ }^{23-27}$.
Ozawa and KAS methods are selected in studying the kinetics of thermal dehydration of the title compound. So, water loss kinetic parameters were evaluated from 
the curves $\ln \left(v / T^{2} \mathrm{~m}\right)=\mathrm{f}(1 / \mathrm{Tm})$ and $\ln (\mathrm{v})=\mathrm{f}(1 / \mathrm{Tm})$ (Figures 8 and 9), where (v) is the heating rate and Tm the sample temperature at the thermal effect maximum. The characteristic temperatures at maximum dehydration rates, $\mathrm{Tm}$ in ${ }^{\circ} \mathrm{C}$, at different heating rates from the DTA curves of $\left(\mathrm{NH}_{3} \mathrm{C}_{6} \mathrm{H}_{4} \mathrm{COOH}\right)_{3} \mathrm{H}_{2} \mathrm{P}_{3} \mathrm{O}_{10} .3 \mathrm{H}_{2} \mathrm{O}$ are gathered in Table 4.

Table 4. Temperatures of endothermic peak summits on the DTA curves of $\left(\mathrm{NH}_{3} \mathrm{C}_{6} \mathrm{H}_{4} \mathrm{COOH}\right)_{3} \mathrm{H}_{2} \mathrm{P}_{3} \mathrm{O}_{10} 3 \mathrm{H}_{2} \mathrm{O}$.

\begin{tabular}{|l|l|l|l|l|l|l|}
\hline heating rates & $1{ }^{\circ} \mathrm{C} / \mathrm{min}$ & $3^{\circ} \mathrm{C} / \mathrm{min}$ & $6^{\circ} \mathrm{C} / \mathrm{min}$ & $10^{\circ} \mathrm{C} / \mathrm{min}$ & $15^{\circ} \mathrm{C} / \mathrm{min}$ & \\
\hline $3 \mathrm{H}_{2} \mathrm{O}$ & 108 & 118 & 134 & 142 & 152 & $\begin{array}{l}\text { Temperatures of } \\
\text { endothermic peak } \\
\text { summits }\left({ }^{\circ} \mathrm{C}\right)\end{array}$ \\
\hline $2 \mathrm{NH}_{3}$ & 161.4 & 174 & 189 & 193.4 & 206 & 206 \\
\hline $1 \mathrm{NH}_{3}$ & 166.6 & 180 & 194 & 198 & 233 & \\
\hline $3 \mathrm{CO}_{2}$ & 181.6 & 197 & 216 & 219 & \\
\hline
\end{tabular}

From these temperatures, the apparent activation energies of dehydration were calculated for the $\left(\mathrm{NH}_{3} \mathrm{C}_{6} \mathrm{H}_{4} \mathrm{COOH}\right)_{3} \mathrm{H}_{2} \mathrm{P}_{3} \mathrm{O}_{10} .3 \mathrm{H}_{2} \mathrm{O}$. For the KissingerAkahira-Sunose (KAS) ${ }^{26}$ method, the slope of the resulting straight line of the curve: $\ln \left(\mathrm{v} / \mathrm{T}^{2} \mathrm{~m}\right)=$ $\mathrm{f}(1 / \mathrm{Tm})$ (Figure 8$)$, equals to :

-Ea/R allows the apparent activation energy to be calculated (Table 4). With reference to the Ozawa method, the slope of the resulting straight line on the curve: $\ln (\mathrm{v})=\mathrm{f}(1 / \mathrm{Tm})$ (Figure 9), equals to $-1.0516 \mathrm{E} / \mathrm{R}$, also allows the apparent activation energy to be calculated by this second way (Table 4). The equations used for the two methods are the following:

for $\mathrm{KAS}^{27}$

$\operatorname{Ln}\left(\frac{v}{T_{m}^{2}}\right)=\operatorname{Ln}\left(\frac{A R}{E}\right)-\left(\frac{E}{R}\right)\left(\frac{1}{T_{m}}\right)$

for Ozawa ${ }^{27}$

$\operatorname{Ln}(v)=\operatorname{Ln}\left(\frac{A R}{1.0516 E}\right)-1.0516\left(\frac{E}{R}\right)\left(\frac{1}{T_{m}}\right)$

The pre-exponential factor or Arrhenius constant (A) and the related thermodynamic functions can be calculated by using the activated complex theory (transition state) of Eyring ${ }^{29-31 .}$ The following general equation can be written ${ }^{31}$ :

$$
A=\left(\frac{e \chi k_{B} T_{m}}{h}\right) \exp \left(\frac{\Delta S^{\bullet}}{R}\right)
$$

Where $\mathrm{e}$ is the Neper number $(\mathrm{e}=2.7183), \chi$ is the transition factor, which is unity for the monomolecular reaction, $\mathrm{k}_{\mathrm{B}}$ is the Boltzmann constant $\left(\mathrm{k}_{\mathrm{B}}=1.3806 \times 10-23 \mathrm{~J} \mathrm{~K}-1\right), \mathrm{h}$ is Plank's constant $(\mathrm{h}=6.6261 \times 10-34 \mathrm{~J} \mathrm{~s}), \mathrm{T}_{\mathrm{m}}$ is the peak temperature of the DTA curve, $R$ is the gas constant $(\mathrm{R}=8.314 \mathrm{~J}$
$\mathrm{K}^{-1} \mathrm{~mol}^{-1}$ ) and $\Delta \mathrm{S}^{*}$ is the entropy change of transition state complex or entropy of activation. Thus, the entropy of activation may be calculated as follows:

$$
\Delta \boldsymbol{S}^{8}=R \operatorname{Ln} \frac{A h}{e \chi k_{n} T_{m}}
$$

The enthalpy change of transition state complex or heat of activation $\left(\Delta \mathrm{H}^{*}\right)$ and Gibbs free energy of activation $\left(\Delta \mathrm{G}^{*}\right)$ of decomposition were calculated according to Eqs. (5) and (6), respectively:

$\Delta \mathrm{H}^{*}=\mathrm{E}^{*}-\mathrm{R} \mathrm{T}_{\mathrm{m}}$

$\Delta \mathrm{G}^{*}=\Delta \mathrm{H}^{*}-\mathrm{T}_{\mathrm{m}} \Delta \mathrm{S}^{*}$

Where, $E^{*}$ is the activation energy $E_{a}$ of both KAS ${ }^{25}$ and Ozawa ${ }^{26}$ methods. The values of the activation energy are gathered in (Table 5). Thermodynamic functions were calculated from Eqs. (4), (5) and (6) and summarized in (Table 6). The negative values of $\Delta S^{*}$ from two methods for the dehydration step reveals that the activated state is less disordered compared to the initial state. These $\Delta S^{*}$ values suggest a large number of degrees of freedom due to rotation which may be interpreted as a «slow » stage ${ }^{30-33}$ in this step. The positive values of $\Delta G^{*}$ at all studied methods are because, the dehydration processes are not spontaneous. The positivity of $\Delta \mathrm{G}^{*}$ is controlled by a small activation entropy and a large positive activation enthalpy according to the Eq. 6 . The endothermic peaks in DTA data agree well with the positive sign of the activation enthalpy $\left(\Delta \mathrm{H}^{*}\right)$. The estimated thermodynamic functions $\Delta \mathrm{S}^{*}$ and $\Delta \mathrm{G}^{*}$ (equation 6, Table 6) from two methods are approximatively the same due to the same preexponential factor of about $10^{12}$. While $\Delta \mathrm{H}^{*}$ (equation 5 , Table 6) exhibits, in all the cases, an independent behavior on the pre-exponential factor as seen from exhibiting nearly the same value. 

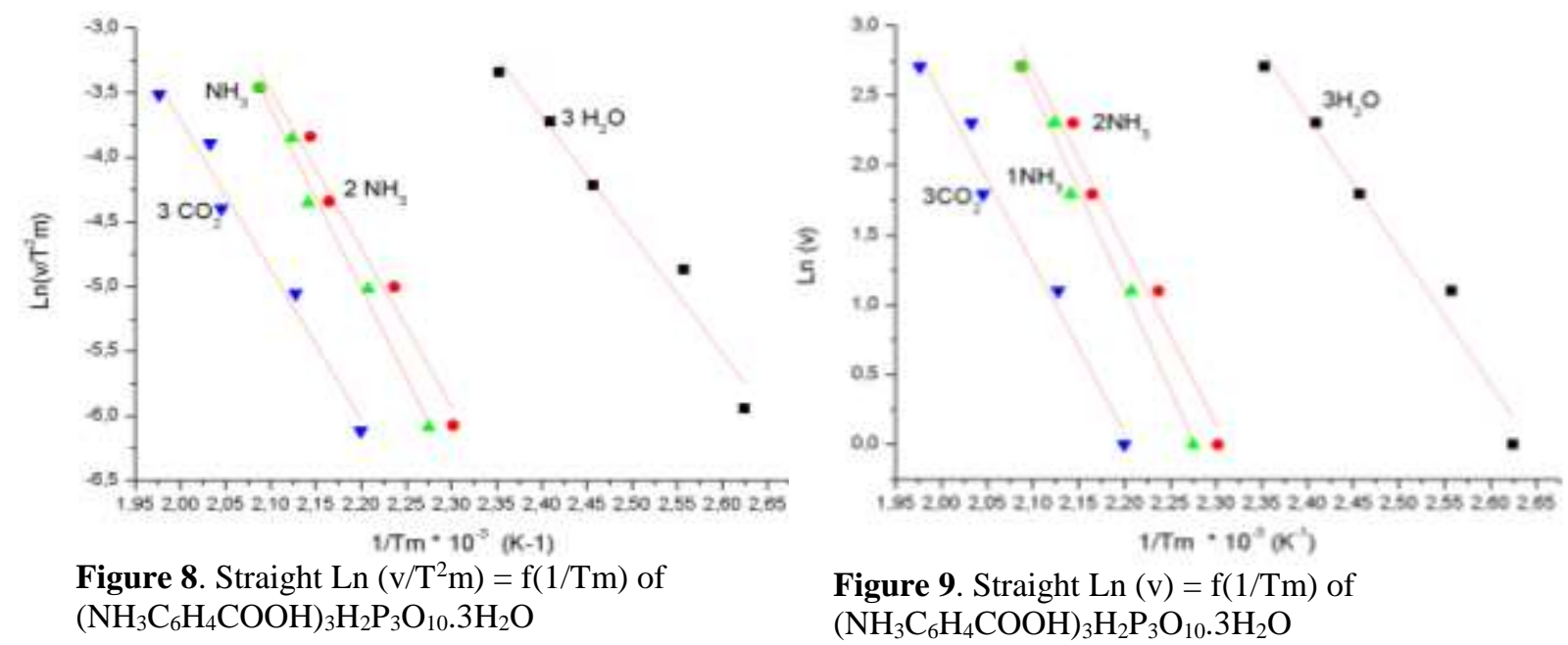

Figure 9. Straight $\mathrm{Ln}(\mathrm{v})=\mathrm{f}(1 / \mathrm{Tm})$ of $\left(\mathrm{NH}_{3} \mathrm{C}_{6} \mathrm{H}_{4} \mathrm{COOH}\right)_{3} \mathrm{H}_{2} \mathrm{P}_{3} \mathrm{O}_{10} .3 \mathrm{H}_{2} \mathrm{O}$

Table 5. Activation energy values Ea, pre-exponential factor $(\mathrm{A})$ and correlation coefficient $\left(\mathrm{r}^{2}\right)$ calculated by Ozawa and KAS methods for the dehydration of $\left(\mathrm{NH}_{3} \mathrm{C}_{6} \mathrm{H}_{4} \mathrm{COOH}\right)_{3} \mathrm{H}_{2} \mathrm{P}_{3} \mathrm{O}_{10} 3 \mathrm{H}_{2} \mathrm{O}$ under atmospheric pressure.

\begin{tabular}{|c|c|c|c|c|c|c|}
\hline & \multicolumn{3}{|c|}{ OZAWA } & \multicolumn{3}{|c|}{ K.A.S } \\
\hline Steps & $\mathrm{Ea}(\mathrm{kJ} / \mathrm{mol})$ & $\begin{array}{c}\mathrm{A} \\
\left(\mathrm{min}^{-1}\right)\end{array}$ & $\mathrm{r}^{2}$ & $\begin{array}{c}\mathrm{Ea} \\
(\mathrm{kJ} / \mathrm{mol})\end{array}$ & $\begin{array}{c}\mathrm{A} \\
\left(\mathrm{min}^{-1}\right)\end{array}$ & $\mathrm{r}^{2}$ \\
\hline $\begin{array}{l}\text { Step } 1 \\
\left(3 \mathrm{H}_{2} \mathrm{O}\right)\end{array}$ & 75.6954 & $2.3714 \times 10^{12}$ & 0.97 & 76.2636 & $8.3937 \times 10^{11}$ & 0.963 \\
\hline Step $2\left(2 \mathrm{NH}_{3}\right)$ & 99.9956 & $7.8151 \times 10^{12}$ & 0.973 & 101.373 & $6.6787 \times 10^{12}$ & 0.97 \\
\hline Step $3\left(1 \mathrm{NH}_{3}\right)$ & 112.9685 & $4.3858 \times 10^{12}$ & 0.99 & 114.992 & $3.6930 \times 10^{12}$ & 0.99 \\
\hline Step $4\left(3 \mathrm{CO}_{2}\right)$ & 92.9084 & $3.9084 \times 10^{12}$ & 0.971 & 96.1057 & $3.0864 \times 10^{12}$ & 0.97 \\
\hline
\end{tabular}

Table 6. Values of $\Delta \mathrm{S} \neq, \Delta \mathrm{H} \neq$ and $\Delta \mathrm{G} \neq$ for dehydration step of $\left(\mathrm{NH}_{3} \mathrm{C}_{6} \mathrm{H}_{4} \mathrm{COOH}\right)_{3} \mathrm{H}_{2} \mathrm{P}_{3} \mathrm{O}_{10} \cdot 3 \mathrm{H}_{2} \mathrm{O}$ calculated according to Ozawa and KAS equations.

\begin{tabular}{|c|c|c|c|c|c|c|}
\hline & \multicolumn{3}{|c|}{ OZAWA } & \multicolumn{3}{|c|}{ K.A.S } \\
\hline Steps & $\begin{array}{c}\Delta \mathrm{S} \\
\left(\mathrm{J} . \mathrm{K}^{-1} \cdot \mathrm{mol}^{-1}\right)\end{array}$ & $\begin{array}{c}\Delta \mathrm{H} \\
\left(\mathrm{kJ} \cdot \mathrm{mol}^{-1}\right)\end{array}$ & $\begin{array}{c}\Delta \mathrm{G} \\
\left(\mathrm{kJ} \cdot \mathrm{mol}^{-1}\right)\end{array}$ & $\begin{array}{c}\Delta \mathrm{S} \\
\left(\mathrm{J} . \mathrm{K}^{-1} \cdot \mathrm{mol}^{-1}\right)\end{array}$ & $\begin{array}{c}\Delta \mathrm{H} \\
\left(\mathrm{kJ} \cdot \mathrm{mol}^{-1}\right)\end{array}$ & $\begin{array}{c}\Delta \mathrm{G} \\
\left(\mathrm{kJ} \cdot \mathrm{mol}^{-1}\right)\end{array}$ \\
\hline Step $1\left(\mathbf{3 H}_{2} \mathrm{O}\right)$ & -19.2678 & 72.1619 & 80.3508 & -27.9027 & 72.7302 & 84.5888 \\
\hline Step $2\left(2 \mathrm{NH}_{3}\right)$ & -10.3472 & 96.0132 & 100.969 & -11.4960 & 97.4661 & 102.869 \\
\hline Step $3\left(1 N H_{3}\right)$ & -15.1501 & 108.98614 & 116.2431 & -16.5795 & 111.0096 & 118.9513 \\
\hline Step $4\left(3 \mathrm{CO}_{2}\right)$ & -16.5641 & 91.0571 & 99.4386 & -18.5271 & 91.8983 & 101.273 \\
\hline
\end{tabular}

\section{Conclusion}

The structural and thermal study of 4-carboxyphenyl dihydrogenotriphosphate ammonium trihydrate $\left(\mathrm{NH}_{3} \mathrm{C}_{6} \mathrm{H}_{4} \mathrm{COOH}\right)_{3} \mathrm{H}_{2} \mathrm{P}_{3} \mathrm{O}_{10} .3 \mathrm{H}_{2} \mathrm{O}$ developed by IR spectrometry vibration and TGA-DTA analyses coupled brings up the following results:

The reaction of phosphoric acid with aminobenzoic acid leads, due to the hydrolysis of $\mathrm{P}_{3} \mathrm{O}_{9}{ }^{3-}$ ion in aqueous solution or by using $\mathrm{H}_{5} \mathrm{P}_{3} \mathrm{O}_{10}$, to a triphosphate with a formula $\left(\mathrm{C}_{7} \mathrm{H}_{8} \mathrm{NO}_{2}\right)_{3} \mathrm{H}_{2} \mathrm{P}_{3} \mathrm{O}_{10} .3 \mathrm{H}_{2} \mathrm{O}$. The structural resolution shows the existence of ion channels $\mathrm{H}_{2} \mathrm{P}_{3} \mathrm{O}_{10}{ }^{3-}$ linked together by hydrogen bonds. Organic cations, water molecules and phosphates chains are linked together by hydrogen bonds. A detailed vibrational study is reported for $\left(\mathrm{NH}_{3} \mathrm{C}_{6} \mathrm{H}_{4} \mathrm{COOH}\right)_{3} \mathrm{H}_{2} \mathrm{P}_{3} \mathrm{O}_{10} \cdot 3 \mathrm{H}_{2} \mathrm{O}$ with all of its entities $\mathrm{NH}_{3}, \mathrm{C}_{6} \mathrm{H}_{4} \mathrm{COOH}, \mathrm{H}_{2} \mathrm{P}_{3} \mathrm{O}_{10}$ and $\mathrm{H}_{2} \mathrm{O}$. The thermal analysis showed that the compound is stable between 25 and $90^{\circ} \mathrm{C}$ and has confirmed the number of water molecules per formula unit. This loss of water takes place in one step and leads to the crystallization of the anhydrous phase, $\left(\mathrm{C}_{7} \mathrm{H}_{8} \mathrm{NO}_{2}\right)_{3} \mathrm{H}_{2} \mathrm{P}_{3} \mathrm{O}_{10}$, which was characterized by its $\mathrm{X}$-ray powder diffraction pattern and IR spectrum. This phase $\left(\mathrm{C}_{7} \mathrm{H}_{8} \mathrm{NO}_{2}\right)_{3} \mathrm{H}_{2} \mathrm{P}_{3} \mathrm{O}_{10}$ was found stable in a small temperature range, $150-160^{\circ} \mathrm{C}$. We have shown that by raising the temperature, the anhydrous phase 
loses successively $3 \mathrm{H}_{2} \mathrm{O}\left((2) \mathrm{NH}_{3},(1) \mathrm{NH}_{3}\right)$ and $3 \mathrm{CO}_{2}$ per formula unit. For each of these entities released, the apparent activation energy was measured. These energies are respectively $73,4 \mathrm{~kJ} / \mathrm{mol}$ for $1 \mathrm{NH}_{3}$ and $92,29 \mathrm{~kJ} / \mathrm{mol}$ for $3 \mathrm{CO}_{2}$. Between 260 and $300^{\circ} \mathrm{C}$, the residual mass, $\left(\mathrm{C}_{6} \mathrm{H}_{5}\right)_{3} \mathrm{H}_{2} \mathrm{P}_{3} \mathrm{O}_{10}$ undergoes a weight loss corresponding to a molar loss of $70 \mathrm{~g} / \mathrm{mol}$. This weight loss is accompanied by an atomic rearrangement which results on the DSC thermogram with a peak at $300^{\circ} \mathrm{C}$. Beyond $300^{\circ} \mathrm{C}$, there is degradation of the organic matrix and / or the mineral matrix. An exothermic peak at the top temperature at $432^{\circ} \mathrm{C}$ could be the combustion of the residue of the organic matrix.

\section{References}

1- S.I. Akberova, New Biological Properties of p-aminobenzoic Acid Biol Bull Russian Acad Sci., 2002, 29: 390-393.

2- N. Benali-Cherif, F. Allouche, A. Direm, and K. Soudani, Hydrogen bonding in 2-carboxyanilinium dihydrogen phosphite at $100 \mathrm{~K}$, Acta Cryst E, 2009, E65, 0064-0065

3- N. Benali-Cherif, F. Allouche, A. Direm, and K. Soudani, Hydrogen bonding in 4carboxyanilinium Dihydrogenphosphate, Acta Cryst E, 2007, E63, 02272-02274

4- N. Benali-Cherif, F. Allouche, A. Direm, and K. Soudani, 4-Carboxyanilinium hydrogensulfate, Acta Cryst E, 2007, E63, 02054-02056

5- N. Benali-Cherif, A. Abouimrane, K. Sbai, H. Merazig, A. Cherouana and L. Bendjeddou, p-Carboxyphenylammonium dihydrogenmonophosphate Monohydrate, Acta Cryst E, 2002, E58, 0160-0161

6- J. Chékir-Mzali, S. Elgharbi, K. HorchaniNaifer, M. Ferid, Synthesis, vibrational characteristic and luminescence properties of $\mathrm{Er}^{3+}$ in $\mathrm{HNH}_{4} \mathrm{ErP}_{3} \mathrm{O}_{10}$, Optical Materials, 2017, 37,188

7- A. Charaf, I. Fahim, EL. M. Tace, M. Tridane, M. Radid and S. Belaaouad, Physico-chemical studies of $\mathrm{CuNa}_{3} \mathrm{P}_{3} \mathrm{O} .12 \mathrm{H}_{2} \mathrm{O}$, crystallographic characterization of $\mathrm{CuNa}_{3} \mathrm{P}_{3} \mathrm{O}$ and quantum chemical calculations of The $\mathrm{PO}_{10}{ }^{5-}$ ion, Phosphorus Research Bulletin, 2010, 24, 83.

8- I. Fahim, A. Kheireddine, M, Tridane, and S. Belaaouad, Chemical preparation and XRD data for a new triphosphate $\mathrm{CuNaP}_{3} \mathrm{O}_{10}$ and two cyclotriphosphates $\mathrm{SrRbP}_{3} \mathrm{O}_{9} \cdot 3 \mathrm{H}_{2} \mathrm{O}$ and $\mathrm{SrRbP}_{3} \mathrm{O}_{9}$, Powder Diffraction, 2011, 26 (1), 78-81.

9- I. Fahim, M. Tridane and S. Belaaouad, Physico-chemical studies of

$\mathrm{MgNa}_{3} \mathrm{P}_{3} \mathrm{O}_{10} .12 \mathrm{H}_{2} \mathrm{O}$, XIIéme Rencontre Marocaine sur la Chimie de l'Etat Solide (REMCES XII), MATEC Web of Conferences, 2013, 5, 04035.

10- M. Tridane, I. Fahim, S. Benmokhtar and S.Belaaouad, Structural modifications from

\section{$\left(\mathrm{NH}_{3} \mathrm{C}_{6} \mathrm{H}_{4} \mathrm{COOH}\right)_{3} \mathrm{H}_{2} \mathrm{P}_{3} \mathrm{O}_{10} .3 \mathrm{H}_{2} \mathrm{O}$}

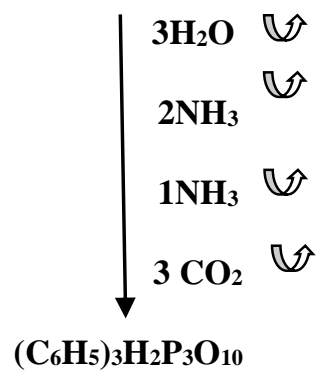

$\mathrm{NiNa}_{3} \mathrm{P}_{3} \mathrm{O}_{10} .12 \mathrm{H}_{2} \mathrm{O}$ to $\mathrm{NiNa}_{3} \mathrm{P}_{3} \mathrm{O}_{10}$ new triphosphate during the dehydration process, Phosphorus Research

11- A. Jouini and A. Durif, Utilisation des résines dans la préparation des phosphates condensés, C R Acad Sci., 1983, 297 II, 573-578,

12- M. Belhabra, S. Zerraf, A. Kheireddine, K. El Kababi, A. atibi, M. tridane, M. Radid, and S. Belaaouad, Chemical preparation and crystallographic characterization of $\mathrm{BaCsP}_{3} \mathrm{O}_{9} .2 \mathrm{H}_{2} \mathrm{O}$, $\left(\mathrm{NH}_{3} \mathrm{C}_{6} \mathrm{H}_{4} \mathrm{COOH}\right)_{3} \mathrm{H}_{2} \mathrm{P}_{3} \mathrm{O}_{10} .3 \mathrm{H}_{2} \mathrm{O} 10$ and it is corresponding anhydrous, $\left(\mathrm{NH}_{3} \mathrm{C}_{6} \mathrm{H}_{4} \mathrm{COOH}\right)_{3} \mathrm{H}_{2} \mathrm{P}_{3} \mathrm{O}_{10}$, Am. J. innov. res. Appl. sci., 2017, 4(6), 223-229.

13- K. El Kababi, A. atibi, R. Lamsatfi, S. Zerraf, I. Fahim, M. Tridane and S. Belaaouad, Chemical Preparation, XRD Data and IR Studies for an Organic Triphosphate and Its Anhydrous New Form $\left(\mathrm{NH}_{3} \mathrm{C}_{6} \mathrm{H}_{4} \mathrm{COOH}\right)_{3} \mathrm{H}_{2} \mathrm{P}_{3} \mathrm{O}_{10}$, International Journal of Trend in Research and Development, 2016, 3(3), 302-305.

14- I. Fahim, A. Kheireddine, S. Belaaouad, Sodium tripolyphosphate (STPP) as a novel corrosion inhibitor for mild steel in $1 \mathrm{M} \mathrm{HCl}$, Journal of Optoelectronics and Advanced Materials, 2013, 15(5-6), 451

15- A. Kheireddine, M. Tridane and S. Belaaouad, Chemical preparation, the kinetics of thermal behavior and infrared studies of $\mathrm{Pb}_{3}\left(\mathrm{P}_{3} \mathrm{O}_{9}\right)_{2} .3 \mathrm{H}_{2} \mathrm{O}$ and $\mathrm{Cd}_{3}\left(\mathrm{P}_{3} \mathrm{O}_{9}\right)_{2} .14 \mathrm{H}_{2} \mathrm{O}$, Mediterr. J. Chem., 2013, 2(4), 549-568

16- A. Atibi, K. El Kababi, M. Belhabra, S. Zerraf, M. Tridane \& S. Belaaouad, Chemical preparation, crystal structure and vibrational study of a new dihydrogenotriphosphate trihydrate of 4-aminobenzoic acid fertilizer type NP, Journal of Coordination Chemistry, 2018, 71(21), 3510-3520

17- M. Samsonowicz, T. Hrynaszkiewicz, R. Swislocka, W. Lewandowski, Experimental and theoretical IR, Raman, NMR spectra of 2-, 3- and 4-aminobenzoic acids, Journal of Molecular Structure, 2005, 744, 345-352 


\section{MEDITERRANEAN JOURNAL OF CHEMISTRY}

18- J. Antony, GV. Helden, G. Meijer, B. A. Schmidt, Anharmonic midinfrared vibrational spectra of benzoic acid monomer and dimer, J Chem Phys, 2005, 123, 014305

19- G.M. Florio, T.S. Zwier, E.M. Myshakin, K.D. Jordan, and E.L. Sibert III, Theoretical modeling of the $\mathrm{OH}$ stretch infrared spectrum of carboxylic acid dimers based on firstprinciples anharmonic couplings, J. Chem. Phys., 2003, 118, 1735

20- Ch. Muthuselvi, A. S. Princy and S. S. Pandiarajan, Growth and Characterization of 4-carboxyanilinium Dihydrogen Phosphate Semi-Organic Complex Crystal, Asian J Applied Sc., 2017, 10(4), 159-169

21- Abraham F. Jalbout, Zhen-Yi Jiang, A. Ouasri, H. Jeghnou, A. Rhandour, M. C.

Dhamelincourt, P. Dhamelincourt, A. Mazzah, Theoretical and experimental vibrational analysis of $\left[\mathrm{C}_{6} \mathrm{H}_{5} \mathrm{NH}_{3}\right]_{2} \mathrm{SiF}_{6}, \mathrm{~J}$ Vibrational Spectroscopy, 2003, 33, 21-30

22- V. Koval, P. Nagornyi, Effect of addition of ammonium dihydrophosphate on the formation of insoluble polyphosphates by condensation of potassium dihydrophosphate at $225^{\circ} \mathrm{C}$, J Appl chem., 1990, 62, 2373

23- M. Bagieu-Beucher, I. Tordjman, A. Durif and J. Guitel, Structure Crystalline du Trimétaphosphate de Potassium $\mathrm{K}_{3} \mathrm{P}_{3} \mathrm{O}_{9}$, Acta Crystallogr., 1976, B32, 1427-1430

24- H. E Kissinger, Reaction Kinetics in Differential Thermal analysis, Anal. Chem., 1957, 29, 1702

25- T. Akahira and T. Sunose, "Transactions joint convention of four electrical institutes, paper no. 246 (1969) research report, Chiba Institute of Technology," Journal of Science Education and Technology, 1971, 16, 22-31.

26- T. A Ozawa, A New Method of Analyzing Thermogravimetric Data, Bull Chem Soc Jpn, 1965, 38, 1881-1886.

27- A. W. Coats, J. P. Redfern, Kinetic Parameters from Thermogravimetric Data, Nature, 1964, 201, 68-69.

28- D. W. Van Krevelns, P.J. Hoftijzer, Kinetics of gas-liquid reaction-general theory, Trans I Chem, 1954, E 32, 5360

29- V. Šatava F. Škvára, Mechanism and Kinetics of the Decomposition of Solids by a Thermogravimetric Method, J. Am. Ceram. Soc., 1969, 52(11), 591-595.

30- J. Rooney, J. Eyring, Eyring transition-state theory and kinetics in catalysis, J Mol Catal A Chemical, 1995, 96, L1-L3.

31- B. Boonchom, Kinetics and Thermodynamic Properties of the Thermal Decomposition of Manganese Dihydrogenphosphate Dihydrate, J Chem Eng Data, 2008, 53, 1533-1538.

32- L. Valaev, N. Nedelchev, K. Gyurova, M. Zagorcheva, A comparative study of nonisothermal kinetics of decomposition of calcium oxalate monohydrate, J Anal Appl Pyrol, 2008, 81, 253-262.

33- P. Noisong, C. Danavirutai, T. Boonchom, Synthesis, characterization and non-isothermal decomposition kinetics of manganese hypophosphite monohydrate, Solid State Sci, 2008, 10, 1598-1604. 